\title{
A biogeochemical model of phytoplankton productivity in an urban estuary: The importance of ammonium and freshwater flow
}

\author{
Richard C. Dugdale*, Frances P. Wilkerson, Alexander E. Parker \\ Romberg Tiburon Center, San Francisco State University, 3152 Paradise Drive, Tiburon, CA 94920, United States
}

\section{A R T I C L E I N F O}

\section{Article history:}

Received 3 February 2013

Received in revised form 14 May 2013

Accepted 15 May 2013

Available online 20 June 2013

\section{Keywords:}

Phytoplankton

Ammonium

Nitrate

Estuary

Bloom

Freshwater flow

Suisun Bay

Regional Index Terms: USA

California

San Francisco Bay

\begin{abstract}
A B S T R A C T
Increased discharge of ammonium $\left(\mathrm{NH}_{4}\right)$ to the San Francisco Estuary (SFE), largely in treated domestic sewage effluent, has been linked to chronically food-limited conditions and to reduced fish abundance. Elevated chlorophyll concentrations at phytoplankton bloom levels are rarely observed if the ambient $\mathrm{NH}_{4}$ concentrations are above $4 \mu \mathrm{mol} \mathrm{L}^{-1}$-the $\mathrm{NH}_{4}$ paradox. In both field samples and water held in enclosures for one week, an inverse relation was observed between $\mathrm{NH}_{4}$ concentrations and nitrate $\left(\mathrm{NO}_{3}\right)$ uptake by phytoplankton, likely a result of inhibition of $\mathrm{NO}_{3}$ uptake by $\mathrm{NH}_{4}$. A simple model was constructed to examine the interaction between $\mathrm{NH}_{4}$ and $\mathrm{NO}_{3}$ inputs to the estuary, with varying freshwater river flow (hereafter termed flow) conditions. Sensitivity analyses were made and initial model parameters taken from an existing oceanic biogeochemistry model. Experiments were made with the model, and showed that initial $\mathrm{NH}_{4}$ concentrations largely controlled the length of time to peak $\mathrm{NO}_{3}$ uptake and $\mathrm{NO}_{3}$ exhaustion. The model parameters were then tuned using observations from a set of enclosure experiments, and validated with results from a series of independent enclosure experiments with a variety of initial conditions. The model was run in three flow modes: (1) with no (zero) flow, (2) with flow, a fully mixed water column and a uniform light field, and (3) with flow, a fully mixed water column but with light attenuation and depth integrated values of $\mathrm{N}$ uptake. In the zero flow mode the model simulated enclosure experiments and when compared with enclosure results indicated the basic $\mathrm{NH}_{4}-\mathrm{NO}_{3}$ interactions to be correctly represented in the model. In the modes with flow, the model simulations reproduced a sharp transition from high phytoplankton productivity using both $\mathrm{NO}_{3}$ and $\mathrm{NH}_{4}$ to low productivity using only $\mathrm{NH}_{4}$, simulating the historical effects of increasing $\mathrm{NH}_{4}$ inputs to the SFE. With vertical integration to incorporate effects of irradiance, sharp boundaries at specific combinations of varying flow and $\mathrm{NH}_{4}$ inputs were observed. The model could be embedded into three dimensional models of the SFE/Delta currently being implemented for management purposes such as regulating estuarine nutrients as required by the State of California and evaluating the effects of water management decisions on salmon and protected species of fish.
\end{abstract}

(C) 2013 Elsevier B.V. All rights reserved.

\section{Introduction}

In the urban San Francisco Estuary (SFE) a rapid decline of four fish species to low population levels suggests that some may be on the verge of extinction. The trend is known as the Pelagic Organism Decline (POD) and a search for the cause(s) has been in progress (e.g. Sommer et al., 2007). Studies have concluded that most levels of the food web above the primary producers are food limited (MüllerSolger et al., 2002; Kimmerer et al., 2005; Sobczak et al., 2005; Greene et al., 2011). The estuary has chronically low primary production (Kimmerer et al., 2012) near the bottom of estuaries listed in order of annual primary production (Boynton et al., 1982; Nixon, 1988). Suisun Bay in the northern SFE (Fig. 1) is a center of attention

\footnotetext{
* Corresponding author. Tel.: +1 415338 3518; fax: +1 4154357120 .

E-mail address: rdugdale@sfsu.edu (R.C. Dugdale).
}

about the causes of the POD since it is where critical phases in the life cycle of one POD species occur. This species, the delta smelt (Hypomesus transpacificus), has been listed as endangered under the California Endangered Species Act since 2008.

Although the current debate on the cause(s) of the POD focuses on the period from 2000 to the present, the primary productivity of the SFE has been declining for more than three decades (Jassby et al., 2002) even though water transparency, previously shown to determine primary production in the SFE (Cole and Cloern, 1984), and nutrient loads have been increasing over the same period (Jassby, 2008). This situation with declining productivity and high nutrients has been termed oligotrophication by Nixon (1990). A trend of increasing chlorophyll in the Delta has occurred in the period 1996-2005, but not in Suisun Bay (Jassby, 2008).

Before 1980, Suisun Bay was characterized as a high chlorophyll ecosystem dominated by diatoms and large zooplankton (Ball and Arthur, 1979); it is now dominated by small phytoplankton, 


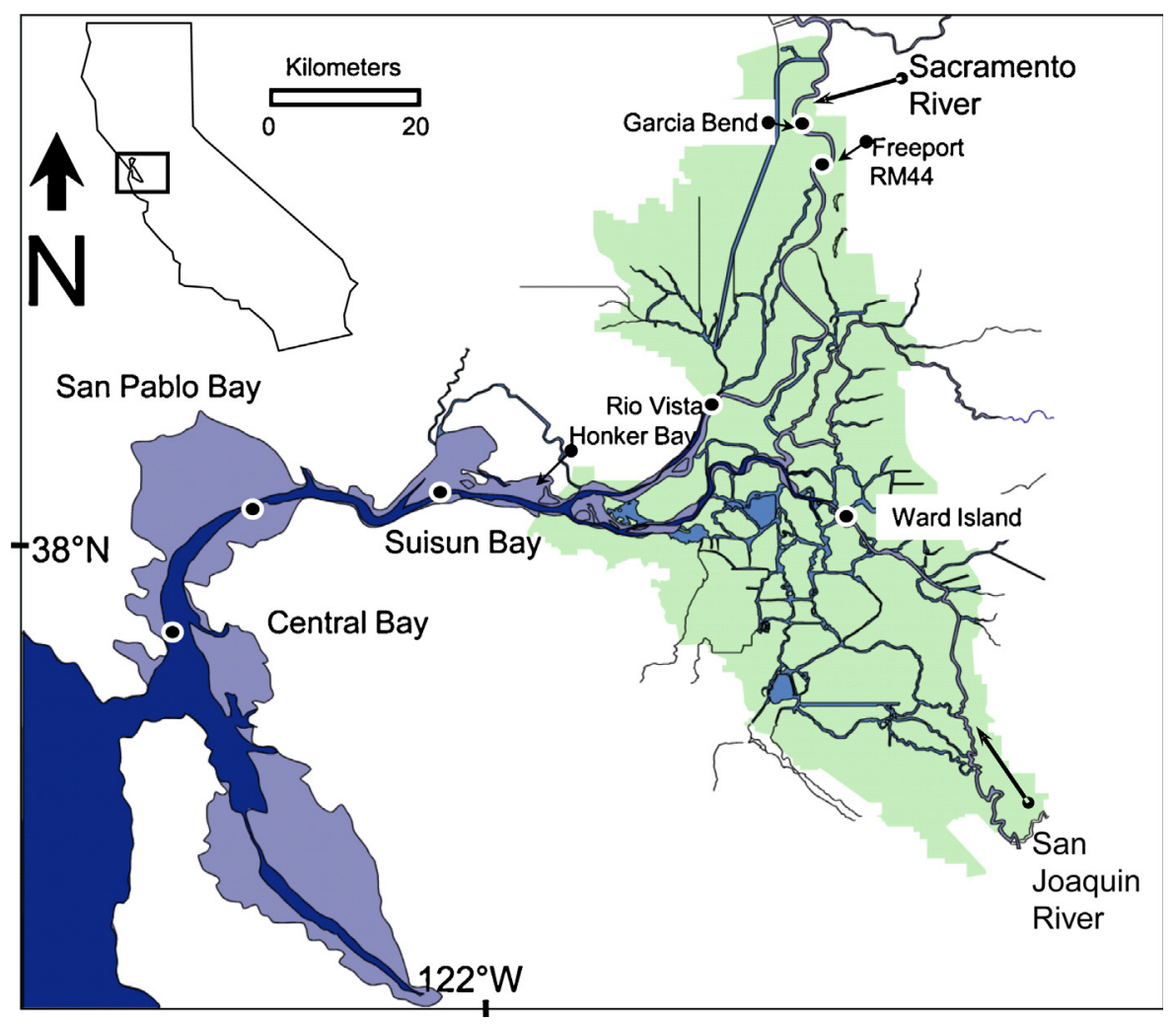

Fig. 1. Map of San Francisco Estuary/Delta California showing Suisun, San Pablo and Central Bays, and sampling locations along the Sacramento and San Joaquin rivers.

small zooplankton (Glibert et al., 2011) and low primary production (Kimmerer et al., 2012). High summer chlorophyll concentrations in Suisun Bay declined to low levels in 1987. Additionally spring blooms were not observed in Suisun Bay (Dugdale et al., 2012). The invasive Asian overbite clam (Potamocorbula amurensis) appeared in substantial numbers at that time and is considered the primary reason for the crash in phytoplankton biomass (Alpine and Cloern, 1992). However clam populations are low in spring (Greene et al., 2011) and grazing is insufficient to explain the lack of spring blooms. Nutrients had been neglected as a factor in regulation of primary production in the SFE as N, Si and P were all in excess of requirements throughout the year (Jassby et al., 2002). However, the decline in chlorophyll in Suisun Bay (in all seasons) began at about the same time as $\mathrm{NH}_{4}$ discharge and concentrations began to increase rapidly in the Sacramento River the main water source for Suisun Bay (Glibert et al., 2011), the result of both increases in urban populations and agricultural use of nitrogen fertilizers (Jassby, 2008). In 1984 there were 5.2 tons $\mathrm{NH}_{4}-\mathrm{N}$ day ${ }^{-1}$ added to the Sacramento River at Freeport from municipal waste (Schemel and Hager, 1986); additional natural/agricultural $\mathrm{NH}_{4}$ in the Sacramento River was less than or equal to half of the effluent input. Today, discharge of $\mathrm{NH}_{4}$ at Freeport is about 15 tons $\mathrm{NH}_{4}-\mathrm{N}$ per day (Jassby, 2008).

A growing body of evidence points to $\mathrm{NH}_{4}$ inputs of anthropogenic origin as a driving factor in the decline and eventual collapse of the primary productivity of the northern SFE and in particular of Suisun Bay (e.g. Dugdale et al., 2007; Glibert et al., 2011; Dugdale et al., 2012). Measurements of dissolved inorganic $\mathrm{N}$ (DIN) uptake by phytoplankton using incubations with ${ }^{15} \mathrm{NO}_{3}$ and ${ }^{15} \mathrm{NH}_{4}$ as tracers have indicated that nutrients in SFE are important in determining phytoplankton productivity (Wilkerson et al., 2006; Dugdale et al., 2007, 2012; Parker et al., 2012a,b). $\mathrm{NO}_{3}$ is rarely used in the SFE/Delta as a consequence of suppression of $\mathrm{NO}_{3}$ uptake by $\mathrm{NH}_{4}$, with phytoplankton blooms occurring in the SFE only when $\mathrm{NH}_{4}$ concentrations declined to low levels (Wilkerson et al., 2006;
Dugdale et al., 2007). $\mathrm{NO}_{3}$ uptake is essential for high productivity rates and phytoplankton bloom occurrence as $\mathrm{NO}_{3}$ is the largest reservoir of DIN in the SFE (Wilkerson et al., 2006; Dugdale et al., 2012). Decreased phytoplankton growth rates and reduced carbon fixation (primary production) occurred when the algae were using $\mathrm{NH}_{4}$ compared to $\mathrm{NO}_{3}$ (Wilkerson et al., 2006; Parker et al., 2012a). When chlorophyll concentrations and $\mathrm{NO}_{3}$ uptake rates were plotted against $\mathrm{NH}_{4}$ concentration, a threshold of about $4 \mu \mathrm{mol} \mathrm{L}^{-1} \mathrm{NH}_{4}$ appeared to delineate the level at which suppression of $\mathrm{NO}_{3}$ uptake occurred. Below this concentration, $\mathrm{NO}_{3}$ uptake was enabled and occurred even more rapidly when $\mathrm{NH}_{4}$ concentrations decreased to $\sim 1 \mu \mathrm{mol} \mathrm{L}^{-1}$ accompanied by a rapid increase in chlorophyll (Dugdale et al., 2007).

To understand the sequence of events involved in the $\mathrm{NH}_{4}$ response by phytoplankton, to use in simulation models, experiments were made with water from Central San Francisco Bay that was enclosed and incubated under natural light. The phytoplankton response in the enclosed water followed the pattern shown in Fig. 2 (taken from Dugdale et al., 2007) that has been repeatedly observed (e.g. Parker et al., 2012a). First $\mathrm{NH}_{4}$ concentrations decreased and then $\mathrm{NO}_{3}$ concentrations decreased rapidly to zero within four days (Fig. 2a and b) (Dugdale et al., 2007). During this four day cycle, the biomass-specific $\mathrm{NO}_{3}$ uptake rate $\left(\mathrm{VNO}_{3}\right)$ increased to a peak at Day 2 or 3 and then declined rapidly as $\mathrm{NO}_{3}$ was depleted (Fig. 2c). The biomass-specific $\mathrm{NH}_{4}$ uptake rate $\left(\mathrm{VNH}_{4}\right)$ remained relatively unchanged or decreased (Fig. 2d). Chlorophyll accumulation (Fig. 2e) occurred as $\mathrm{NO}_{3}$ was drawn down. This rapid use of $\mathrm{NO}_{3}$ observed in SFE water is virtually identical to that observed in newly upwelled ocean water (Wilkerson and Dugdale, 1987; Dugdale et al., 2006) and incorporated into a productivity model that included acceleration or "shift up" of $\mathrm{NO}_{3}$ uptake rates (Dugdale et al., 1990). The essential feature of this shift-up model is that the biomass specific $\mathrm{NO}_{3}$ uptake rate, $\mathrm{VNO}_{3}$ (equivalent to a nitrogen-based growth rate) increases at a rate proportional to the ambient $\mathrm{NO}_{3}$ concentration. Since $\mathrm{NO}_{3}$ is usually 

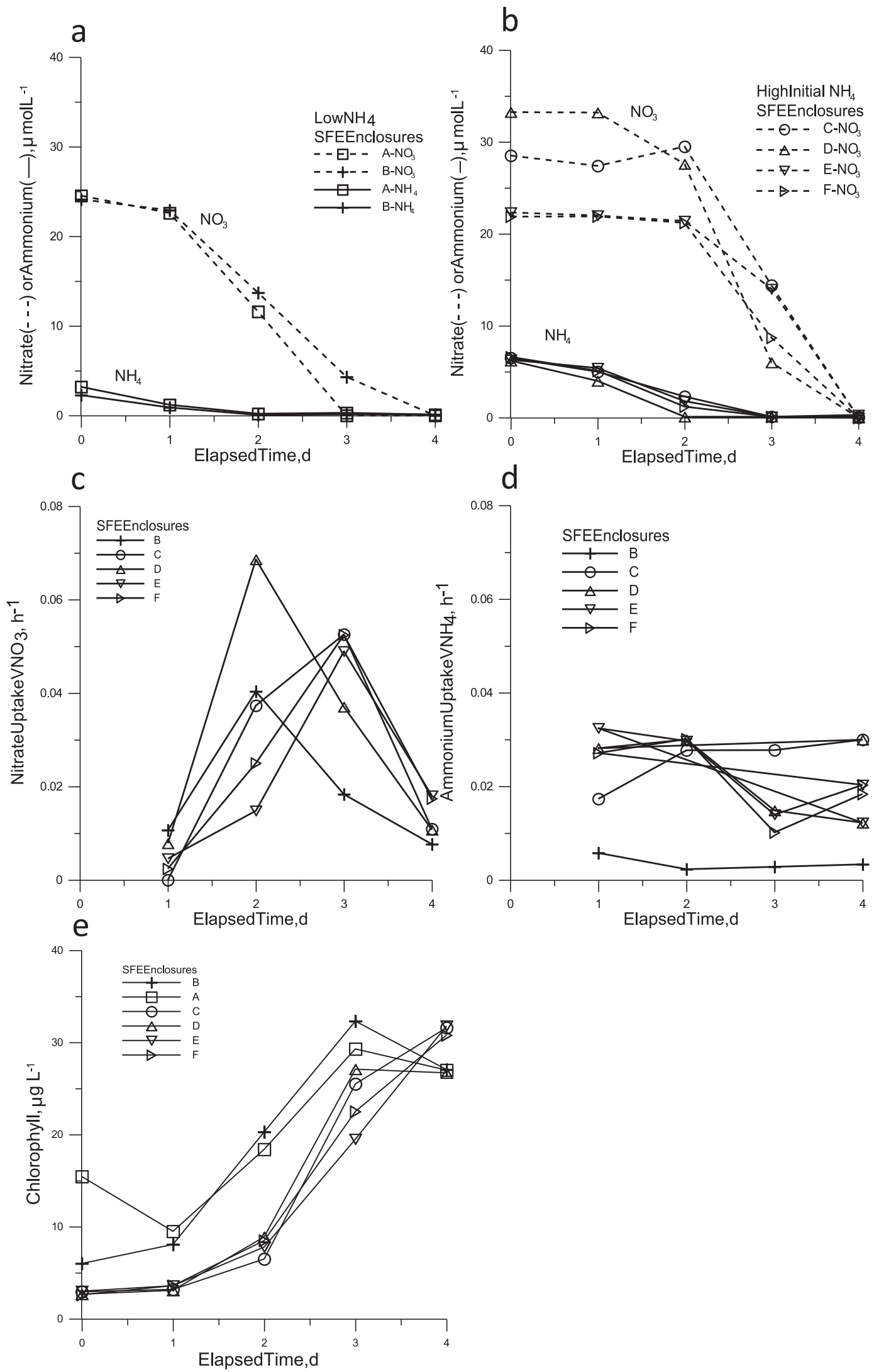

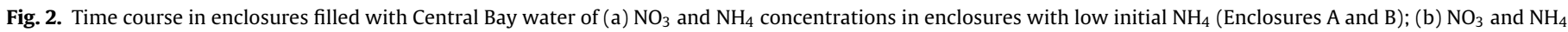
concentrations in enclosures with high initial $\mathrm{NH}_{4}$ (Enclosures C, D, E, F); (c) specific uptake rates of $\mathrm{NO}_{3}$, (d) specific uptake rates of $\mathrm{NH}_{4}$; (e) chlorophyll concentration (from Dugdale et al., 2007). 


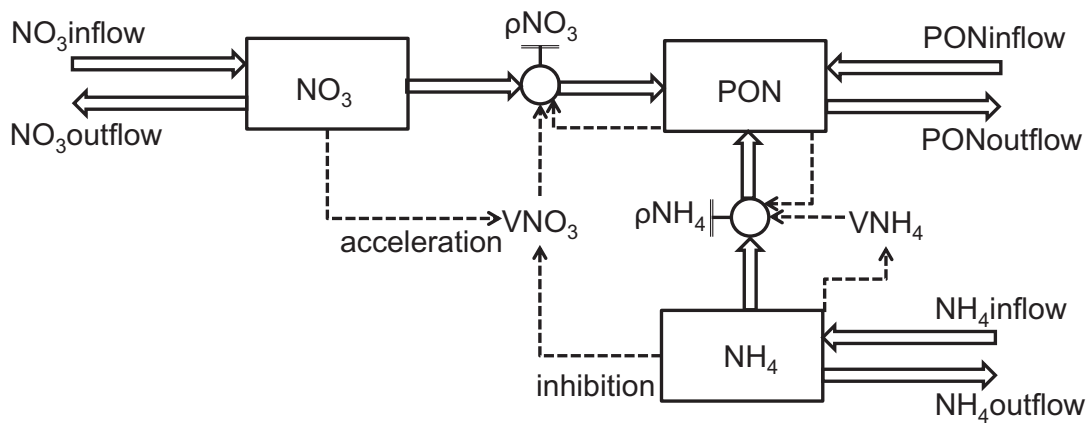

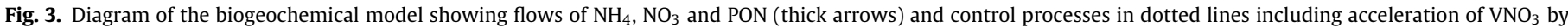
$\mathrm{NO}_{3}$ and inhibition of $\mathrm{VNO}_{3}$ by $\mathrm{NH}_{4}$.

the largest DIN pool in the SFE this will lead to enhanced growth when it is used compared to $\mathrm{NH}_{4}$, that is typically the smaller pool of DIN. The effect can be seen in the $\mathrm{VNO}_{3}$ vs. elapsed time curve for enclosure D (Fig. 2c) which has the steepest slope and is the enclosure with the highest initial $\mathrm{NO}_{3}$ concentration (Fig. 2b). Consequently, $\mathrm{VNO}_{3}$ increases with time until $\mathrm{NO}_{3}$ concentration falls to the Michaelis-Menten limiting range for uptake. This accounts for the result, that all $\mathrm{NO}_{3}$ is exhausted by the phytoplankton in the same length of time, about 4 days, regardless of the initial ambient $\mathrm{NO}_{3}$ (Fig. 2a and b).

In the northern SFE rare spring blooms are enabled by access to the $\mathrm{NO}_{3}$ pool accompanied by high productivity rates when $\mathrm{NH}_{4}$ concentrations are low (Wilkerson et al., 2006; Dugdale et al., 2012). In the period 2000-2010, in Suisun Bay, only two phytoplankton blooms were observed in Suisun Bay: the first in 2000 (Wilkerson et al., 2006) and a second in 2010 (Dugdale et al., 2012). Both blooms ( $>30 \mu \mathrm{g} \mathrm{L}^{-1}$ chlorophyll) occurred when $\mathrm{NH}_{4}$ concentrations were about $1 \mu \mathrm{mol} \mathrm{L}^{-1}$ (Dugdale et al., 2012). Dugdale et al. (2012) developed a conceptual model for the prediction of blooms in Suisun Bay with three required criteria $\left(\mathrm{NH}_{4}\right.$ loading criterion, $\mathrm{NH}_{4}$ concentration criterion and a washout river flow criterion). This analysis highlighted the combined importance of freshwater (river) flow and $\mathrm{NH}_{4}$ concentration in determining bloom initiation in the northern SFE.

A more complete understanding of the role of anthropogenic $\mathrm{NH}_{4}$ and flow in modulating productivity in the SFE will require the development of linked biogeochemical and hydrodynamic models. Here, we evaluate potential productivity of Suisun Bay using a simple biogeochemical model. The model is based on results from field and enclosure experiments conducted in the northern SFE and constructed to be run in a three modes: (1) with no (zero) flow, (2) with flow, a fully mixed water column and a uniform light field, and (3) with flow, a fully mixed water column but with light attenuation and depth integrated values of $\mathrm{N}$ uptake. From resulting model runs we make predictions for the potential effects of managed perturbations in the Suisun Bay ecosystem, e.g. reduction in allowable discharge of anthropogenic $\mathrm{NH}_{4}$ in sewage effluent and/or changes in freshwater flow.

\section{Model development and construction}

Our strategy was to construct a biogeochemical simulation model, linking $\mathrm{NH}_{4}$ and $\mathrm{NO}_{3}$ inputs, phytoplankton uptake, and freshwater flow, make initial runs with zero flow (mode 1 ) to compare with data collected using enclosure experiments, and then tune the model as necessary to reproduce the observed effect of $\mathrm{NH}_{4}$ on $\mathrm{NO}_{3}$ uptake. The model was tested (without flow) against an independent data set from enclosure experiments. Finally the model was run with added freshwater flow effects (modes 2 and 3). The model was constructed and run using Stella 10.0
(Ieesystems.com). The flows and controls are shown in Fig. 3 and the parameters listed in Table 1 with the values used for different model runs in Table 2 . The currency of the model is nitrogen and the pools are $\mathrm{NO}_{3}, \mathrm{NH}_{4}$, and particulate nitrogen (PON). Inflows and outflows are allowed for all three pools. In constructing this model, we drew upon our previous work in developing a biogeochemical ecosystem model - the CoSiNE (Carbon, Silicate, Nitrogen Ecosystem) model (Chai et al., 2002; Dugdale et al., 2002) that has been incorporated into Pacific basin-wide and coastal ROMS models (e.g. Xiu and Chai, 2012), reproducing many important features of these ecosystems. The present model incorporates CoSiNE phytoplankton uptake kinetics (Michaelis-Menten formulation) and an exponential function $(\psi)$ for $\mathrm{NH}_{4}$ inhibition of $\mathrm{NO}_{3}$ uptake (Chai et al., 2002).

The SFE biogeochemical model incorporates kinetic parameters from the CoSiNE model (Chai et al., 2002), appropriate for diatoms which are the major functional group that dominates the final population in enclosure experiments in SFE and in phytoplankton blooms in Suisun Bay (Parker et al., 2012a; Dugdale et al., 2012; Cloern and Dufford, 2005). Diatoms are fast-growing and outcompete other phytoplankton in high nutrient conditions, e.g. in coastal upwelling. They prefer, and under some conditions physiologically require $\mathrm{NO}_{3}$ over $\mathrm{NH}_{4}$ (Syrett, 1981; Berg et al., 2001; Glibert et al., 2006). The model incorporates the concept of shift up, i.e. acceleration of $\mathrm{NO}_{3}$ uptake which is not included in the CoSiNE formulation. The formulation for the acceleration of $\mathrm{NO}_{3}$ uptake $(\mathrm{A})$ to calculate maximum specific $\mathrm{NO}_{3}$ uptake is a function of $\mathrm{NO}_{3}$ concentration as used in Dugdale et al. (1990). The model is run with a time step of

Table 1

List of model parameters and units.

\begin{tabular}{|c|c|}
\hline Parameter & Unit \\
\hline Flow & $\mathrm{m}^{3} \mathrm{~s}^{-1}$ \\
\hline $\mathrm{NH}_{4}(t)$ & $\mu \mathrm{mol} \mathrm{L}^{-1}$ \\
\hline $\mathrm{NH}_{4}$ inflow & $\mu \mathrm{mol} \mathrm{L}^{-1} \mathrm{~h}^{-1}$ \\
\hline $\mathrm{NH}_{4}$ outflow & $\mu \mathrm{mol} \mathrm{L}^{-1} \mathrm{~h}^{-1}$ \\
\hline$\rho \mathrm{NH}_{4}$ & $\mu \mathrm{mol} \mathrm{L}^{-1} \mathrm{~h}^{-1}$ \\
\hline $\mathrm{VNH}_{4}$ & $\mathrm{~h}^{-1}$ \\
\hline $\mathrm{NO}_{3}(t)$ & $\mu \mathrm{mol} \mathrm{L}^{-1}$ \\
\hline $\mathrm{NO}_{3}$ inflow & $\mu \mathrm{mol} \mathrm{L}^{-1} \mathrm{~h}^{-1}$ \\
\hline $\mathrm{NO}_{3}$ outflow & $\mu \mathrm{mol} \mathrm{L}^{-1} \mathrm{~h}^{-1}$ \\
\hline$\rho \mathrm{NO}_{3}$ & $\mu \mathrm{mol} \mathrm{L}^{-1} \mathrm{~h}^{-1}$ \\
\hline $\mathrm{VNO}_{3}$ & $\mathrm{~h}^{-1}$ \\
\hline $\operatorname{PON}(t)$ & $\mu \mathrm{mol} \mathrm{L}^{-1}$ \\
\hline PON inflow & $\mu \mathrm{mol} \mathrm{L}^{-1} \mathrm{~h}^{-1}$ \\
\hline PON outflow & $\mu \mathrm{mol} \mathrm{L}^{-1} \mathrm{~h}^{-1}$ \\
\hline$V_{\max } \mathrm{NH}_{4}$ & $\mathrm{~h}^{-1}$ \\
\hline $\mathrm{K}_{\mathrm{S}} \mathrm{NH}_{4}$ & $\mu \mathrm{mol} \mathrm{L}^{-1}$ \\
\hline $\mathrm{K}_{\mathrm{S}} \mathrm{NO}_{3}$ & $\mu \mathrm{mol} \mathrm{L}^{-1}$ \\
\hline$\alpha$ & $\mathrm{h}^{-2}$ \\
\hline$\beta$ & $\mathrm{h}^{-2}$ \\
\hline$\psi$ & dimensionless \\
\hline
\end{tabular}


Table 2

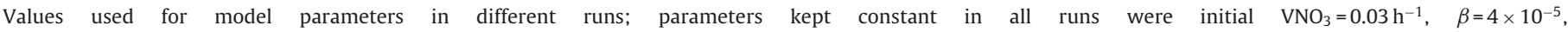
$\psi=-5.59, \mathrm{~K}_{\mathrm{S}} \mathrm{NH}_{4}=1 \mu \mathrm{mol} \mathrm{L}^{-1}, \mathrm{~K}_{\mathrm{S}} \mathrm{NO}_{3}=1 \mu \mathrm{mol} \mathrm{L}^{-1}$.

\begin{tabular}{|c|c|c|c|c|c|c|}
\hline Figure \# & Enclosure Exp. & $\mathrm{NH}_{4}(\mathrm{i})\left(\mu \mathrm{mol} \mathrm{L}^{-1}\right)$ & $\mathrm{NO}_{3}(\mathrm{i})\left(\mu \mathrm{mol} \mathrm{L}^{-1}\right)$ & $\mathrm{PON}(\mathrm{i})\left(\mu \mathrm{mol} \mathrm{L}^{-1}\right)$ & $\alpha\left(\times 10^{-5} \mathrm{~h}^{-2}\right)$ & $A\left(\mathrm{~h}^{-2}\right)$ \\
\hline 4 & & 6.0 & 30.0 & 3.0 & 4 & 0.00124 \\
\hline 4 & & 6.0 & 20.0 & 3.0 & 4 & 0.00084 \\
\hline 5 & & 2.0 & 30.0 & 3.0 & 4 & 0.00124 \\
\hline 5 & & 2.0 & 20.0 & 3.0 & 4 & 0.00084 \\
\hline 7 & Enclosure A & 2.3 & 24.1 & 7.2 & 8 & 0.00197 \\
\hline 7 & Enclosure C & 6.5 & 28.5 & 3.4 & 8 & 0.00232 \\
\hline 7 & Enclosure E & 6.3 & 22.3 & 3.6 & 8 & 0.00182 \\
\hline 8-XB2002 & Control & 6.8 & 18.7 & 4.5 & 8 & 0.00153 \\
\hline 8-ХB2002 & $+5 \mathrm{NH}_{4}$ & 12.4 & 18.7 & 4.5 & 8 & 0.00153 \\
\hline 8-XB2002 & $+10 \mathrm{NH}_{4}$ & 17.9 & 18.7 & 4.5 & 8 & 0.00153 \\
\hline 8-XB2002 & $+20 \mathrm{NH}_{4}$ & 26.0 & 18.7 & 4.5 & 8 & 0.00153 \\
\hline 8-XB2002 & $+30 \mathrm{NH}_{4}$ & 36.0 & 18.7 & 4.5 & 8 & 0.00153 \\
\hline 9-WB09-1 & Garcia Bend & 1.0 & 13.1 & 3.0 & 8 & 0.00109 \\
\hline 9-WB09-1 & Garcia $+\mathrm{NH}_{4}$ & 12.4 & 13.3 & 3.6 & 8 & 0.00111 \\
\hline 9-WB09-1 & $\mathrm{Garcia}+\mathrm{NO}_{3}$ & 1.5 & 24.6 & 4.0 & 8 & 0.00201 \\
\hline 9-WB09-1 & RM44 & 12.4 & 13.3 & 3.6 & 8 & 0.00111 \\
\hline 10-Bad Suisun 3 & Central Bay & 7.6 & 24.1 & 6.7 & 8 & 0.00124 \\
\hline 10-Bad Suisun 3 & Suisun Bay & 3.8 & 43.7 & 6.8 & 8 & 0.00354 \\
\hline 10-Bad Suisun 3 & Rio Vista & 9.0 & 19.2 & 3.1 & 8 & 0.00158 \\
\hline 10-Bad Suisun3 & San Joaquin & 5.1 & 26.2 & 3.7 & 8 & 0.00124 \\
\hline 11 Fixed flow & Variable $\mathrm{NH}_{4}$ & $0.1-10.0$ & 30.0 & 3.0 & 4 & 0.00124 \\
\hline 12-Variable flow & Integrated mode & 5.0 and 10.0 & 30.0 & 6.8 & 4 & 0.00124 \\
\hline 13-Variable flow & variable $\mathrm{NH}_{4}$, integrated mode & $1.0-10.0$ & 30.0 & 3.0 & 8 & 0.00244 \\
\hline
\end{tabular}

one hour, consistent with the units reported for the kinetic parameters for $\mathrm{N}$ uptake. The model is stable at this time step and no gain in precision is likely to be achieved by using smaller time steps. To evaluate daily rates, since $\mathrm{NO}_{3}$ uptake occurs over $12 \mathrm{~h}$ and $\mathrm{NH}_{4}$ uptake over $18 \mathrm{~h}$ (Wilkerson et al., 2000) each hourly rate is multiplied by 0.5 for $\mathrm{NO}_{3}$ uptake and by 0.75 for $\mathrm{NH}_{4}$.

Equations governing the model are:

To determine $\mathrm{NH}_{4}$ balance in an embayment:

$$
\mathrm{NH}_{4}(t)=\mathrm{NH}_{4}(t-\mathrm{d} t)+\left(\mathrm{NH}_{4} \text { inflow }-\rho \mathrm{NH}_{4}-\mathrm{NH}_{4} \text { outflow }\right) \times \mathrm{d} t
$$

where $\mathrm{NH}_{4}(t)$ is $\mathrm{NH}_{4}$ after time, $t$; $\mathrm{d} t$ is the time interval $(1 \mathrm{~h})$ and

$$
\mathrm{NH}_{4} \text { inflow }=\mathrm{NH}_{4}(\mathrm{i}) \times \text { flow }
$$

and

$$
\rho \mathrm{NH}_{4}=V \mathrm{NH}_{4} \times \mathrm{PON} \times 0.75
$$

where $\mathrm{VNH}_{4}$ is biomass specific uptake rate $\left(\mathrm{h}^{-1}\right)$ and $\mathrm{PON}$ is particulate organic nitrogen concentration (i.e. phytoplankton biomass) and $\mathrm{NH}_{4}(\mathrm{i})$ is initial $\mathrm{NH}_{4}$ concentration.

$\mathrm{NH}_{4}$ outflow $=\mathrm{NH}_{4} \times$ flow

To determine $\mathrm{NO}_{3}$ balance:

$\mathrm{NO}_{3}(t)=\mathrm{NO}_{3}(t-\mathrm{d} t)+\left(\mathrm{NO}_{3}\right.$ inflow $-\rho \mathrm{NO}_{3}-\mathrm{NO}_{3}$ outflow $) \times \mathrm{d} t$

$\mathrm{NO}_{3}$ inflow $=\mathrm{NO}_{3}(\mathrm{i}) \times$ flow

$\rho \mathrm{NO}_{3}=\mathrm{VNO}_{3} \times \mathrm{PON} \times 0.5$

$\mathrm{NO}_{3}$ outflow $=\mathrm{NO}_{3} \times$ flow

To determine PON balance:

$\operatorname{PON}(t)=\operatorname{PON}(t-\mathrm{d} t)+\left(\rho \mathrm{NO}_{3}+\rho \mathrm{NH}_{4}\right.$

+ PON inflow - PON outflow) $\times \mathrm{d} t$
$\mathrm{PON}$ inflow $=\mathrm{PON}(\mathrm{i}) \times$ flow

PON outflow $=$ PON $\times$ flow

To determine phytoplankton uptake rates

$V \mathrm{NH}_{4}=V_{\max } \mathrm{NH}_{4} \times \frac{\mathrm{NH}_{4}}{\mathrm{NH}_{4}+\mathrm{K}_{\mathrm{S}} \mathrm{NH}_{4}}$

$V \mathrm{NO}_{3}=\left(V \mathrm{NO}_{3}(\mathrm{i})+A \times t\right) \times \frac{\mathrm{NO}_{3}}{\mathrm{~K}_{\mathrm{S}} \mathrm{NO}_{3}+\mathrm{NO}_{3}} \times \exp ^{\left(-y \times \mathrm{NH}_{4}\right)}$

$A=\alpha \times \mathrm{NO}_{3}+\beta$

where $A$ is acceleration of uptake, $\mathrm{K}_{5} \mathrm{NH}_{4}$ and $\mathrm{K}_{5} \mathrm{NO}_{3}$ are half saturation constants, $\Psi$ is a constant for $\mathrm{NH}_{4}$ inhibition of $\mathrm{NO}_{3}$ uptake.

The equations unique to this model are the inhibition of $\mathrm{NO}_{3}$ uptake by $\mathrm{NH}_{4}$, by an exponential effect with parameter $\Psi$ and the increase of maximal $\mathrm{NO}_{3}$ uptake with time by the acceleration term $A$. The term $A$ has two elements, $\alpha$ which is multiplied by the ambient $\mathrm{NO}_{3}$ concentration, and a constant $\beta$ (Dugdale et al., 1990); both have units of $\mathrm{t}^{-2} . \alpha$ is the more important element. For example, with $\mathrm{NO}_{3}=30 \mu \mathrm{mol} \mathrm{L}^{-1}$, elapsed time of $240 \mathrm{~h}$, and $\alpha=4 \times 10^{-5} \mathrm{~h}^{-2}$, an increase of $V \mathrm{NO}_{3}$ of $0.29 \mathrm{~h}^{-1}$ results while $\beta \times t$ for the same period results in an increase of only $0.01 \mathrm{~h}^{-1}$, about $3 \%$ of the increase due to $\alpha$. Parameters used in each model run and associated with each figure are provided in Table 2 . For the initial model runs to simulate enclosures, the values of $\Psi$ were taken from Chai et al. (2002). Data supplied to the model are initial concentrations of $\mathrm{NH}_{4}, \mathrm{NO}_{3}$ and $\mathrm{PON}$ and in modes 2 and 3, freshwater flow.

\section{Model runs with zero flow}

3.1. Model run with zero flow, variable initial $\mathrm{NO}_{3}$, high initial $\mathrm{NH}_{4}$ concentration

The way the model works is illustrated in Fig. 4, the results of model runs at two initial $\mathrm{NO}_{3}$ concentrations $\left(20\right.$ or $30 \mu \mathrm{mol} \mathrm{L}^{-1}$ ) and initial $\mathrm{NH}_{4}$ at $6 \mu \mathrm{mol} \mathrm{L}-1$. No change in $\mathrm{NO}_{3}$ concentration 

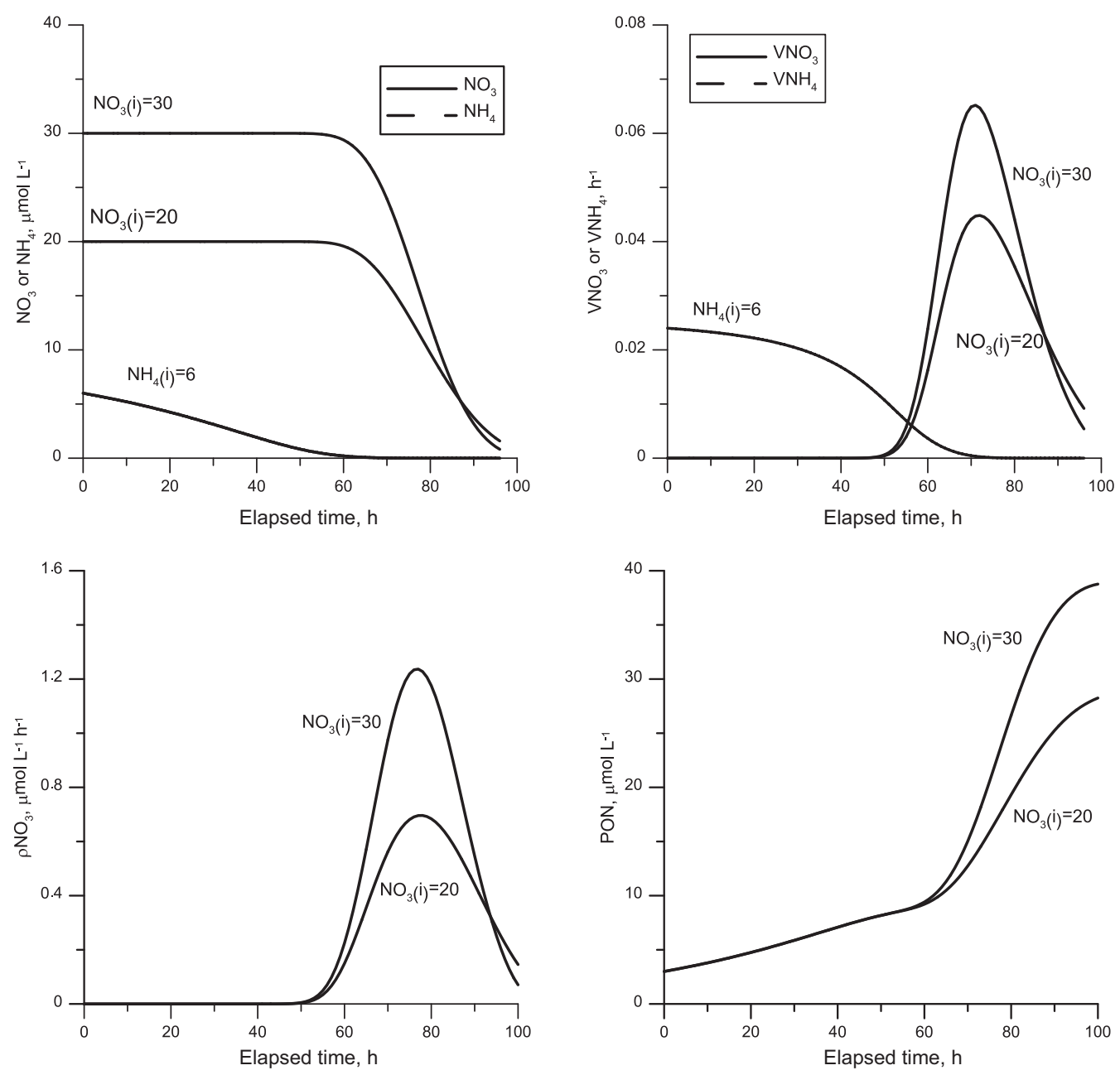

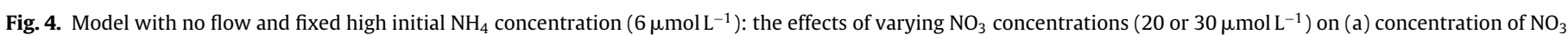
and $\mathrm{NH}_{4}$; (b) specific uptake rates of $\mathrm{NO}_{3}$ and $\mathrm{NH}_{4}$; (c) uptake rate $(\rho)$ of $\mathrm{NO}_{3}$; (d) $\mathrm{PON}$ concentration versus elapsed time.

occurs until $\mathrm{NH}_{4}$ concentration declines to low, non-inhibiting concentrations as a result of $\mathrm{NH}_{4}$ uptake by the phytoplankton (Fig. 4a). The time to exhaust the initial $\mathrm{NO}_{3}$ is the same for both conditions, $96 \mathrm{~h}$, regardless of the initial $\mathrm{NO}_{3}$ concentration, as previously described for the shift-up model (Dugdale et al., 1990). The processes leading to this result occur in a sequence. First, there is an increase in $\mathrm{NO}_{3}$ uptake on a biomass basis $\left(\mathrm{VNO}_{3}\right)$ associated with increasing $\mathrm{NO}_{3}$ concentration, which peaks at $72 \mathrm{~h}$ (Fig. 4b). This increase in uptake is a result of the acceleration term, $A$ (Eqs. (13) and (14)) such that the initial slope of the $\mathrm{VNO}_{3}$ vs. time curve is steeper for the higher $\mathrm{NO}_{3}$ concentration. The peak $\mathrm{VNO}_{3}$ (Fig. $4 \mathrm{~b}$ ) occurs as $\mathrm{NO}_{3}$ concentrations decline (Fig. 4a), acceleration rates decrease and $\mathrm{VNO}_{3}$ begins to decline (Fig. 4b). The peak $\mathrm{VNO}_{3}$ is higher for the higher initial $\mathrm{NO}_{3}$ concentration as a result of the higher initial acceleration rates. The timing of the $\mathrm{VNO}_{3}$ peak, at about $72 \mathrm{~h}$ for both initial $\mathrm{NO}_{3}$ concentrations is largely dependent on the shape of the $\mathrm{NO}_{3}$ concentration versus time curve (Fig. 4a). For the first $60 \mathrm{~h}$, biomass (PON) increases at a relatively low rate due to $\mathrm{NH}_{4}$ uptake and then increases rapidly (Fig. 4d) as $\mathrm{NO}_{3}$ uptake begins. The actual (transport) uptake rate $\rho \mathrm{NO}_{3}$ is the product of $\mathrm{VNO}_{3}$ and PON concentration, (Eq. (7)). In the low $\mathrm{NH}_{4}$ period $\mathrm{VNO}_{3}$ is increasing and $\mathrm{PON}$ is also accumulating with the result that a rapid increase in $\rho \mathrm{NO}_{3}$ occurs (Fig. 4c). The peak in $\rho \mathrm{NO}_{3}$ (Fig. 4c; $79 \mathrm{~h}$ ) occurs slightly later than the peak $\mathrm{VNO}_{3}$ (Fig. $4 \mathrm{~b} ; 72 \mathrm{~h}$ ) delayed due to the continuing accumulation of biomass as PON partially compensating for the decline in $\mathrm{VNO}_{3}$. The final result is a more rapid increase in PON and a higher concentration of PON with the higher initial $\mathrm{NO}_{3}$.

\subsection{Model run with zero flow, variable initial $\mathrm{NO}_{3}$, low initial} $\mathrm{NH}_{4}$ concentration

With lower initial $\mathrm{NH}_{4}$ concentration (i.e. $2 \mu \mathrm{mol} \mathrm{L}^{-1}$ ), and initial $\mathrm{NO}_{3}$ of 20 or $30 \mu \mathrm{mol} \mathrm{L}^{-1}, \mathrm{NO}_{3}$ concentration (Fig. 5a) declines earlier than in the high $\mathrm{NH}_{4}$ concentration runs (Fig. 4a). The time of $\mathrm{NO}_{3}$ exhaustion (at $96 \mathrm{~h}$ ) is virtually the same for the different initial $\mathrm{NO}_{3}$ values, (Fig. $5 \mathrm{a}$ ) and at high $\mathrm{NH}_{4}$ initial concentrations (Fig. 4a). The peak values of $\mathrm{VNO}_{3}$ are still a direct function of the initial $\mathrm{NO}_{3}$ concentration (Fig. 5b), but the curves are broader with time and occur about $10 \mathrm{~h}$ earlier (at $62 \mathrm{~h}$ elapsed time) than with higher initial $\mathrm{NH}_{4}$ concentration (Section 3.1, Fig. 4b). The $\mathrm{NO}_{3}$ uptake $\left(\rho \mathrm{NO}_{3}\right)$ curves (Fig. $5 \mathrm{c}$ ) are broader in the low $\mathrm{NH}_{4}$ runs. As in the high initial $\mathrm{NH}_{4}$ runs, the uptake peaks of $\rho \mathrm{NO}_{3}$ (Fig. 5c) are delayed relative to $\mathrm{VNO}_{3}$ (Fig. 5b), a result of the delay in accumulation of biomass as PON (Fig. 5d). As in the runs with high $\mathrm{NH}_{4}$ concentration, these patterns are controlled largely by the rates of decline of $\mathrm{NO}_{3}$, which starts earlier in the low $\mathrm{NH}_{4}$ runs, but ends at the same time as the high $\mathrm{NH}_{4}$ concentration runs, a consequence of the shift-up model 

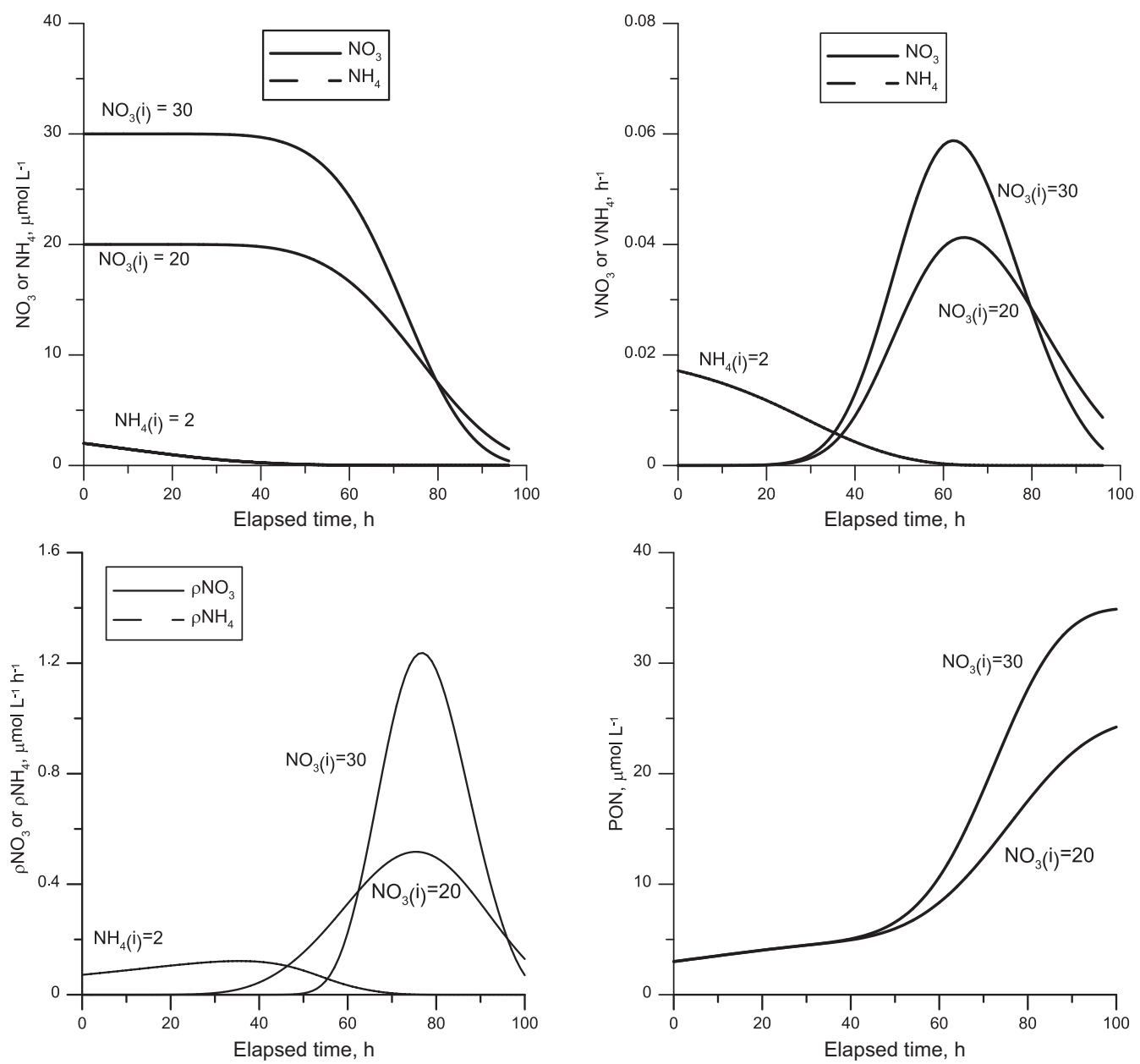

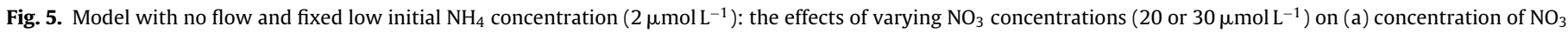
and $\mathrm{NH}_{4}$; (b) specific uptake rates of $\mathrm{NO}_{3}$ and $\mathrm{NH}_{4}$; (c) uptake rate $(\rho)$ of $\mathrm{NO}_{3}$; (d) PON concentration versus elapsed time.

property of $\mathrm{NO}_{3}$ exhaustion occurring at a relatively constant time regardless of the initial $\mathrm{NO}_{3}$ concentration.

\subsection{Sensitivity analysis}

\subsubsection{Effects of parameters on the time to $\mathrm{NO}_{3}$ depletion to zero}

The $\mathrm{NH}_{4}$ uptake rate determines the elapsed time before $\mathrm{NO}_{3}$ uptake occurs. The value of $\mathrm{K}_{5} \mathrm{NH}_{4}$ affects the rate of $\mathrm{NH}_{4}$ uptake (Eq. (12)) and a sensitivity analysis was made of the influence of $\mathrm{K}_{5} \mathrm{NH}_{4}$ on the model output. The time to zero $\mathrm{NO}_{3}$ appears as a linear function of $\mathrm{K}_{\mathrm{S}} \mathrm{NH}_{4}$ (Fig. 6a) but the dependence of the time to $\mathrm{NO}_{3}$ exhaustion was not very sensitive to the value of $\mathrm{K}_{5} \mathrm{NH}_{4}$, increasing the time to exhaustion by only $40 \mathrm{~h}$, from 120 to $160 \mathrm{~h}$. Diatoms are components of the ecosystem that are of the "r" type that compete on the basis of fast growth rates rather than on the ability to take up nutrients at low concentrations i.e. low $\mathrm{K}_{\mathrm{S}}$. High growth rates $\left(V_{\max }\right)$ are usually correlated with high $\mathrm{K}_{\mathrm{S}}$ values. The effect of different initial $\mathrm{NH}_{4}$ concentrations on the time to exhaustion was shown to be small in model runs (Figs. 4 and 5) so it would be expected that $\mathrm{K}_{5} \mathrm{NH}_{4}$ values also have little effect on time to exhaustion.

The effect of $\mathrm{K}_{\mathrm{S}} \mathrm{NO}_{3}$ is small as it occurs only late, when $\mathrm{NO}_{3}$ concentration drops rapidly (not shown). The time to $\mathrm{NO}_{3}$ exhaustion is strongly dependent on the acceleration term, in particular the element $\alpha$. With $\alpha=0 \mathrm{~h}^{-2}$, the time to $\mathrm{NO}_{3}$ exhaustion is about $220 \mathrm{~h}$, but drops to $110 \mathrm{~h}$ at $\alpha=4 \times 10^{-5} \mathrm{~h}^{-2}$ with little changes at higher values (Fig. 6b). The value of $\psi$ has little effect on the time for $\mathrm{NO}_{3}$ exhaustion (Fig. 6c).
3.3.2. Effects of parameters on peak $\mathrm{VNO}_{3}$ and time of peak $\mathrm{VNO}_{3}$

The value of $\mathrm{K}_{5} \mathrm{NH}_{4}$ has little effect on the peak value of $\mathrm{VNO}_{3}$ (Fig. 6d), but affects the time that peak $\mathrm{VNO}_{3}$ is reached (Fig. 6d), from $\sim 50 \mathrm{~h}$ at $\mathrm{K}_{\mathrm{S}} \mathrm{NH}_{4}=0 \mu \mathrm{mol} \mathrm{L}^{-1}$ to nearly $150 \mathrm{~h}$ at $\mathrm{K}_{\mathrm{S}} \mathrm{NH}_{4}=3 \mu \mathrm{mol} \mathrm{L}-1$, a 3-fold increase. The peak value of $\mathrm{VNO}_{3}$ is a nearly linear function of $\alpha$, increasing from 0.02 to $0.12 \mathrm{~h}^{-1}$ at $\alpha=10 \times 10^{-5} \mathrm{~h}^{-2}$ (Fig. 6e). The time at which the peak value of $\mathrm{VNO}_{3}$ is reached occurs at $180 \mathrm{~h}$ with $\alpha=0 \mathrm{~h}^{-2}$ and drops to $60 \mathrm{~h}$ at $\alpha=1 \times 10^{-5} \mathrm{~h}^{-2}$; little change in $\mathrm{VNO}_{3}$ occurs at higher $\alpha$ (Fig. 6e). The greatest effect of $\psi$ on $\mathrm{VNO}_{3}$ and time to peak $\mathrm{VNO}_{3}$ is observed between $\psi=0$ (no inhibition) to $\psi=-2$; above that value little change in $\mathrm{VNO}_{3}$ occurs (Fig. 6f).

Responses to $\pm 50 \%$ changes in parameters from the standard model run conditions are shown in Table 3. Changes in $\mathrm{K}_{\mathrm{S}} \mathrm{NH}_{4}$ result in little change in time to $\mathrm{NO}_{3}$ exhaustion or to peak $\mathrm{VNO}_{3}$, but a $-50 \%$ change in $\mathrm{K}_{5} \mathrm{NH}_{4}$ results in a $-15 \%$ change in time of the peak $\mathrm{VNO}_{3}$. The $50 \%$ perturbation of $\alpha$ results in a $+20 \%$ and $-10 \%$ change in time to $\mathrm{NO}_{3}$ exhaustion, a $-38 \%$ to $+35 \%$ change in peak $\mathrm{VNO}_{3}$, and $\mathrm{a}+10 \%$ to $-3 \%$ change in time of peak $\mathrm{VNO}_{3}$. The maximum response due to a $50 \%$ perturbation of $\psi$ is a $4 \%$ reduction in peak $\mathrm{VNO}_{3}$.

\subsection{Model calibration, zero flow mode (to simulate enclosures)}

Trials of the model were first made using initial input parameters from a series of enclosure experiments (Enclosure $A$ (experiment named 9901), Enclosure C (9903) and Enclosure E 

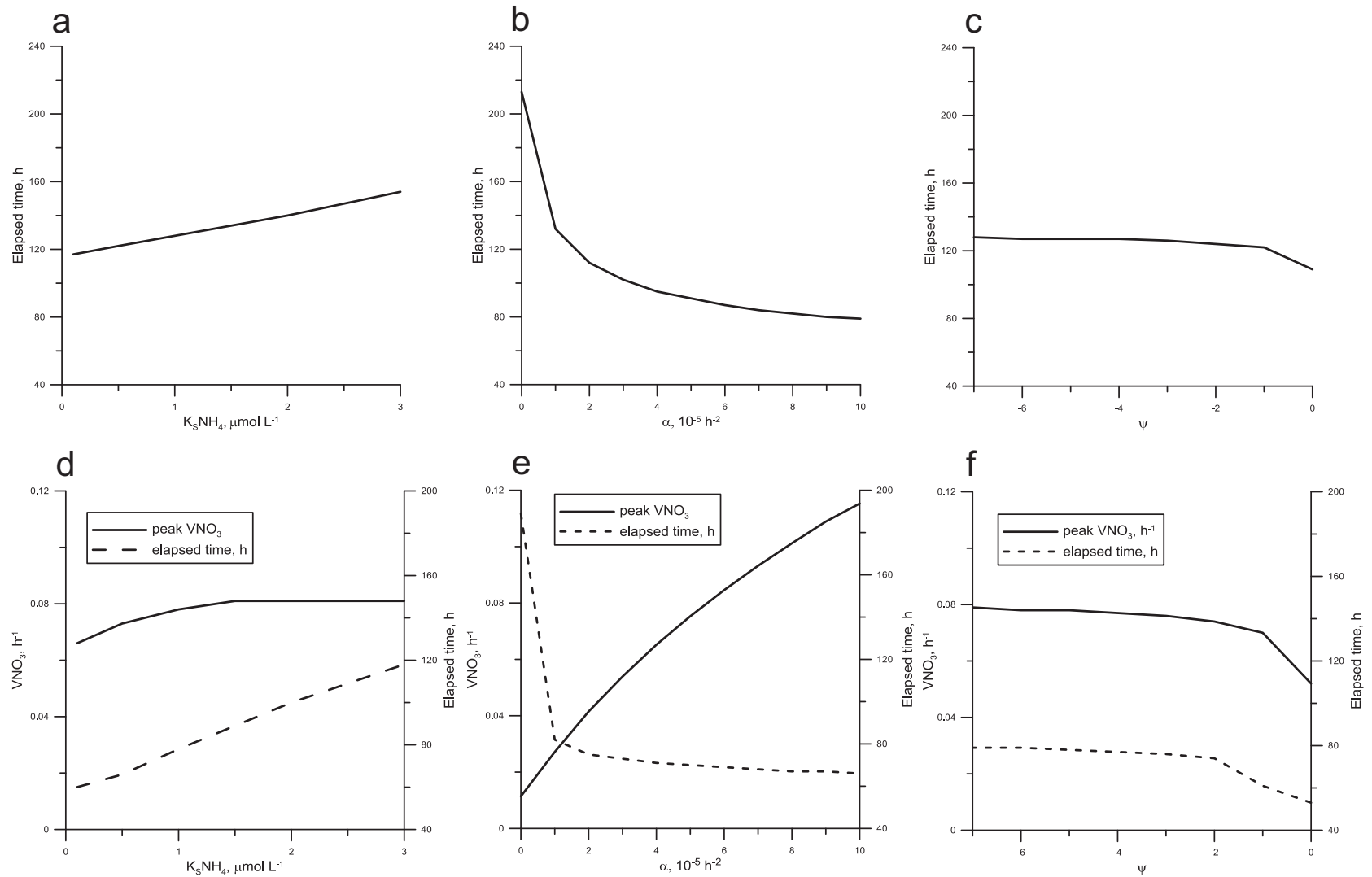

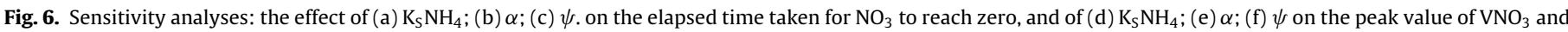
the elapsed time to reach peak $\mathrm{VNO}_{3}$.

(9905A), described Dugdale et al. (2007) (Fig. 2). Water collected in Central Bay (Fig. 1), was incubated under natural light attenuated by $50 \%$ with window screening and cooled with running bay water. $\mathrm{NO}_{3}$ and $\mathrm{NH}_{4}$ uptake rates were obtained using ${ }^{15} \mathrm{~N}$ tracers. Enrichments were at $10 \%{ }^{15} \mathrm{~N}$ to avoid increases in concentrationforced uptake rates (Dugdale and Wilkerson, 1986). Modeled $\mathrm{NH}_{4}$ and $\mathrm{NO}_{3}$ concentration (obtained using the initial $\mathrm{NH}_{4}, \mathrm{NO}_{3}, \mathrm{PON}$ ) in enclosures and observed enclosure data are plotted against time in Fig. 7a, d, g for three enclosures. In all cases a good visual fit of the modeled $\mathrm{NH}_{4}$ and observed data is obtained. Modeled concentrations of $\mathrm{NO}_{3}$ using $\alpha=4 \times 10^{-5} \mathrm{~h}^{-2}$ to calculate acceleration of uptake $A$, do not decline rapidly enough to fit the data. However, when the model is run with $\alpha=8 \times 10^{-5} \mathrm{~h}^{-2}$, a good visual fit is obtained. Plots of $\mathrm{NO}_{3}$ vs. time for two additional values of $\psi,-1.0$ and -2.0 with $\alpha=8 \times 10^{-5} \mathrm{~h}^{-2}$ (Fig. 7a) show very little change, consistent with results in Table 3 , Section 3.3. The small number of experimental data points makes it difficult to make standard statistical evaluations. However, the mean difference for $\mathrm{NH}_{4}$ concentration between model and observations for all three enclosures was $0.3 \mu \mathrm{mol} \mathrm{L}^{-1}$ with a standard deviation of $0.4 \mu \mathrm{mol} \mathrm{L}^{-1}$. For $\mathrm{NO}_{3}$, the mean difference between model and observed data was $-0.7 \mu \mathrm{mol} \mathrm{L}^{-1}$ with a standard deviation of $2.3 \mu \mathrm{mol} \mathrm{L}^{-1}$.

Modeled $\rho \mathrm{NO}_{3}$ are plotted along with enclosure data (Fig. $7 \mathrm{~b}$, e, h) for simulations run at $\alpha=8 \times 10^{-5} \mathrm{~h}^{-2}$. The visual fit is good except for the Day 4 point for enclosure A (9901) (Fig. 7b) when measured $\mathrm{NO}_{3}$ concentration was zero but a positive uptake rate was measured, an artifact of added tracer ${ }^{15} \mathrm{NO}_{3}$. The mean difference between model and observed data for $\rho \mathrm{NO}_{3}$ was $0.1 \mu \mathrm{mol} \mathrm{L}-1 \mathrm{~h}^{-1}$ with a standard deviation of $0.12 \mu \mathrm{mol} \mathrm{L}^{-1} \mathrm{~h}^{-1}$. The simulated pattern of $\mathrm{VNO}_{3}$ (Fig. $7 \mathrm{c}, \mathrm{f}, \mathrm{i}$ ) has the same pattern as $\rho \mathrm{NO}_{3}$ but $\mathrm{VNO}_{3}$ (Fig. $7 \mathrm{c}, \mathrm{f}, \mathrm{i}$ ) are well simulated, with more

Table 3

Sensitivity analysis.

\begin{tabular}{|c|c|c|c|c|c|c|c|}
\hline Parameter & $\begin{array}{l}\text { \%change from } \\
\text { standard run }\end{array}$ & $\begin{array}{l}\text { Time to } \mathrm{NO}_{3}=0 \\
\text { (h) }\end{array}$ & $\begin{array}{l}\text { \%change from } \\
\text { standard run }\end{array}$ & $\begin{array}{l}\text { Peak } \mathrm{VNO}_{3} \\
\left(\mathrm{~h}^{-1}\right)\end{array}$ & $\begin{array}{l}\text { \%change from } \\
\text { standard run }\end{array}$ & $\begin{array}{l}\text { Elapsed time at } \\
\text { peak } \mathrm{VNO}_{3}(\mathrm{~h})\end{array}$ & $\begin{array}{l}\text { \%change from } \\
\text { standard run }\end{array}$ \\
\hline \multicolumn{8}{|c|}{$\mathrm{K}_{\mathrm{S}} \mathrm{NH}_{4}\left(\mu \mathrm{mol} \mathrm{L}^{-1}\right)$} \\
\hline 1 & 100 & 128 & 0.0 & 0.078 & 0.0 & 78 & 0.0 \\
\hline 0.5 & -50 & 122 & -4.7 & 0.073 & -6.4 & 66 & -15.4 \\
\hline 1.5 & 50 & 134 & 4.7 & 0.081 & 3.9 & 89 & 14.1 \\
\hline \multicolumn{8}{|c|}{$\alpha\left(\times 10^{-5} \mathrm{~h}^{-2}\right)$} \\
\hline 4 & 100 & 128 & 0.0 & 0.078 & 0.0 & 78 & 0.0 \\
\hline 2 & -50 & 153 & 19.5 & 0.048 & -38.5 & 85 & 9.0 \\
\hline 6 & 50 & 115 & -10.2 & 0.105 & 34.6 & 76 & -2.6 \\
\hline \multicolumn{8}{|l|}{$\psi$} \\
\hline-5.59 & 100 & 128 & 0.0 & 0.078 & 0.0 & 78 & 0.0 \\
\hline-2.80 & -50 & 126 & -1.6 & 0.075 & -3.9 & 76 & -2.6 \\
\hline-8.39 & 50 & 129 & 0.8 & 0.080 & 2.6 & 80 & 2.6 \\
\hline
\end{tabular}




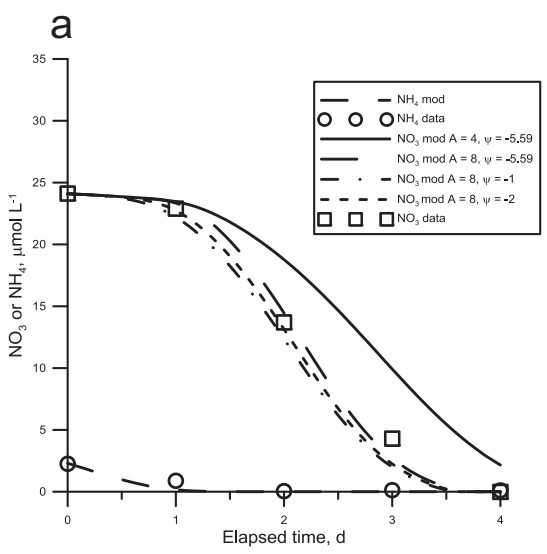

d

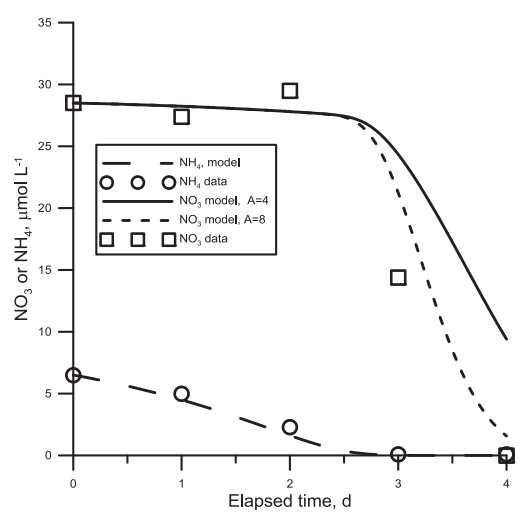

g

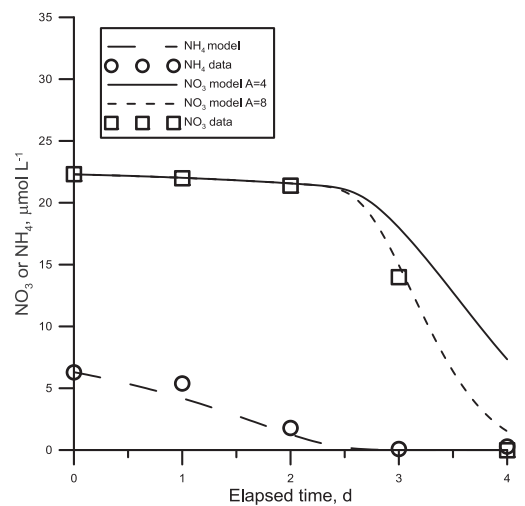

$\mathrm{b}$

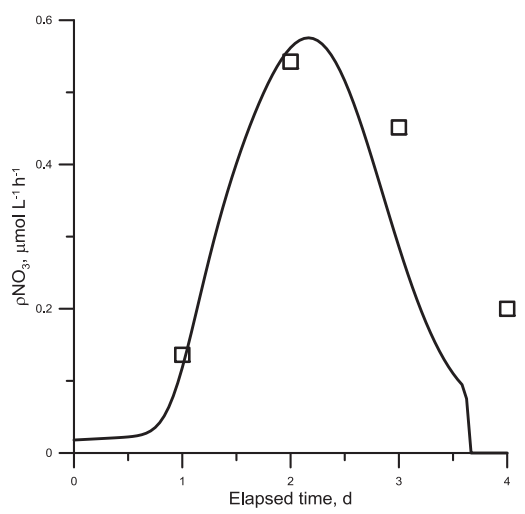

e

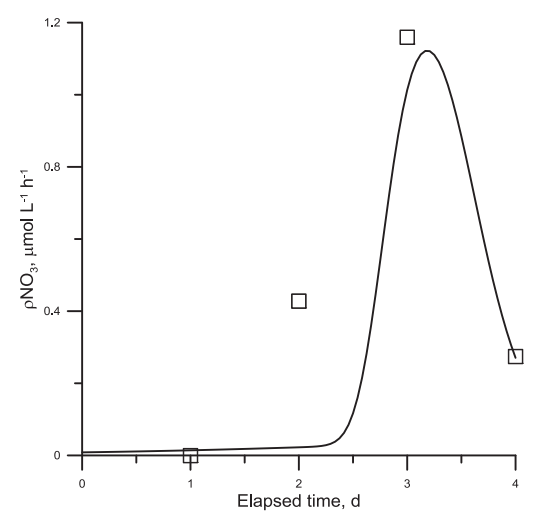

$\mathrm{h}$

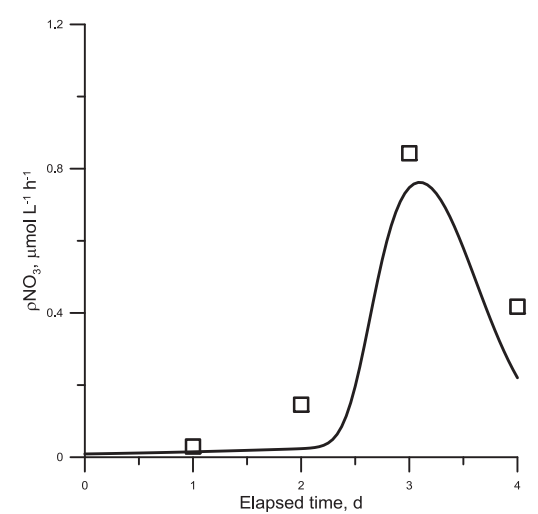

C

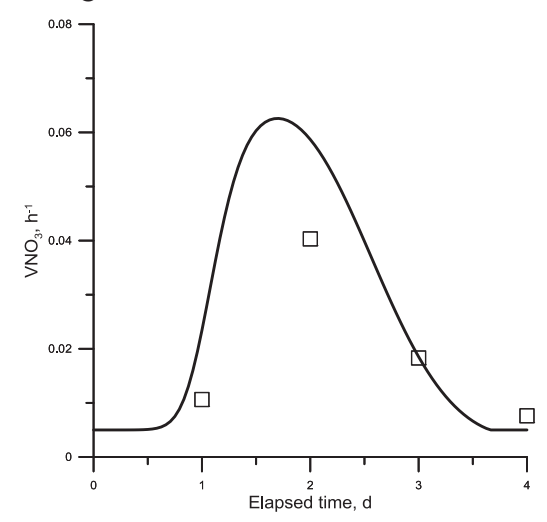

$\mathrm{f}$
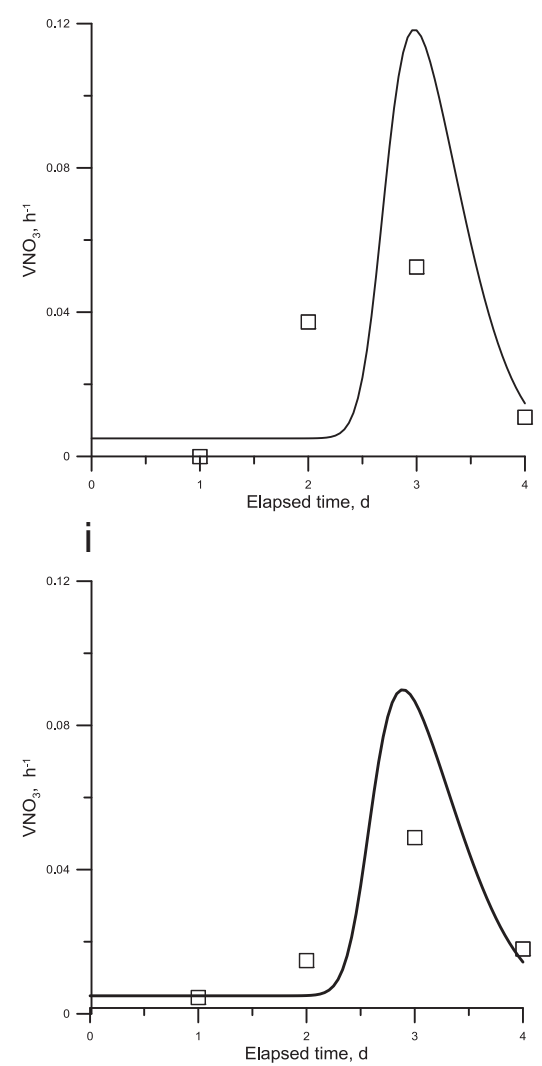

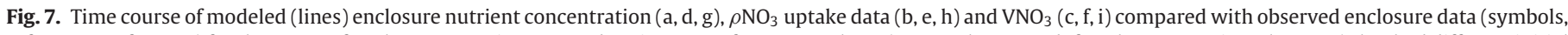

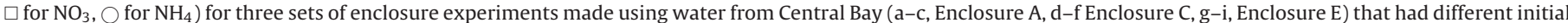

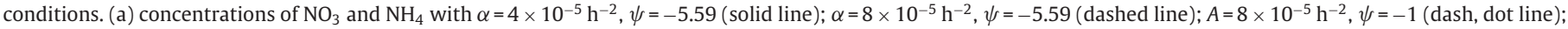
$\alpha=8 \times 10^{-5} \mathrm{~h}^{-2}, \psi=-2$ (dotted line); (d, g) concentrations of $\mathrm{NO}_{3}$ and $\mathrm{NH}_{4}$ with $\alpha=4 \times 10^{-5} \mathrm{~h}^{-2}, \psi=-5.59$ (solid line); $\alpha=8 \times 10^{-5} \mathrm{~h}^{-2}, \psi=-5.59$ (dashed line).

variability in the observed data due to the presence of detrital-N in the PON pool being measured using mass spectrometry. However, the values of $\rho \mathrm{NO}_{3}$ are robust as any detrital particulate $\mathrm{N}$ that dilutes the $\mathrm{VNO}_{3}$ is canceled by the higher PON (Dugdale and Wilkerson, 1986). The only parameter that was varied to obtain a fit of the model and Central Bay enclosure data concentration pattern with time was $\alpha$ in the calculation of acceleration, $A$.

\subsection{Model validation using independent data}

Initial data were used from independent observation data sets of enclosures filled with water from Central and Suisun Bays and Sacramento and San Joaquin rivers to initialize the model and compare modeled uptake rates and biomass accumulation with observed data.

\subsubsection{Enclosures from the Central Bay ("XB2003'“) experiment}

Manipulated enclosure experiments (XB2003) were made in which additions of $\mathrm{NH}_{4}$ were made, at $5,10,20$ and $30 \mu \mathrm{mol} \mathrm{L}^{-1}$ to water collected from Central Bay (Fig. 1) and the effects followed for four days (see Dugdale et al., 2007). Each enclosure was sampled daily for nutrient and chlorophyll concentrations, and ${ }^{15} \mathrm{NH}_{4}$ and ${ }^{15} \mathrm{NO}_{3}$ uptake incubations made with $50 \%$ ambient irradiance, cooled with flowing bay water.

The time course of modeled concentrations of $\mathrm{NO}_{3}$ and $\mathrm{NH}_{4}$, and uptake are plotted along with the data from the five enclosures in Fig. $8 \mathrm{a}-$ j. The modeled exhaustion point for $\mathrm{NH}_{4}$ (i.e. to reach zero) 

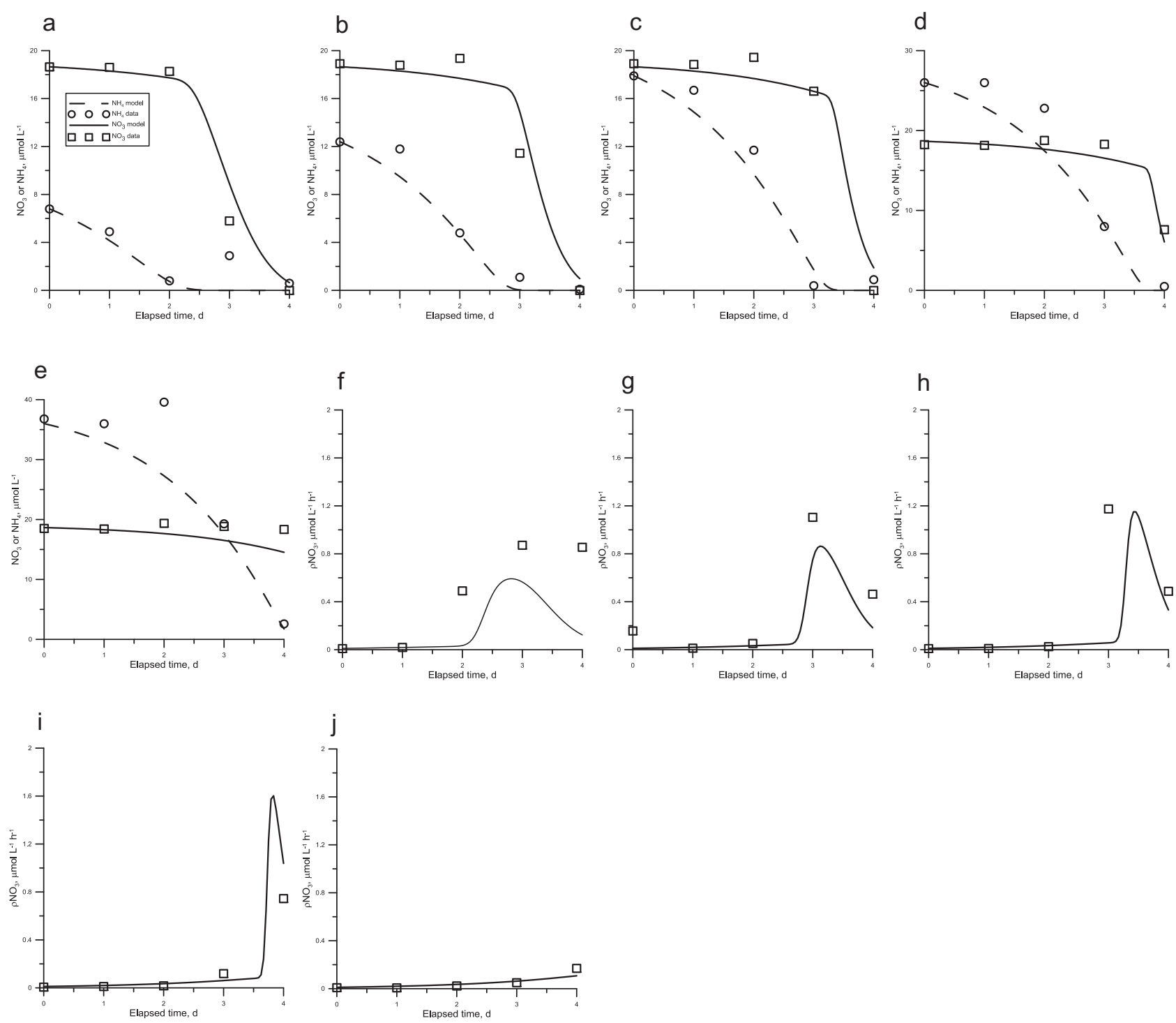

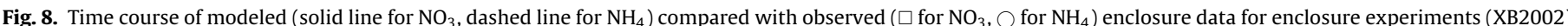

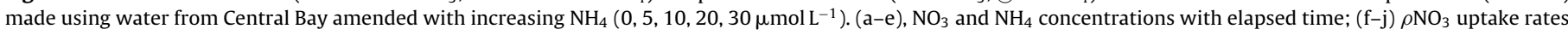
with elapsed time.

is well simulated for all enclosures (Fig. 8a-e) with some indications of initial lag in the measured decline in $\mathrm{NH}_{4}$ in the two highest $\mathrm{NH}_{4}$ addition enclosures, 20 and $30 \mu \mathrm{mol} \mathrm{L}^{-1}$ (Fig. 8d and e). The initiation of $\mathrm{NO}_{3}$ drawdown is progressively delayed by increasing $\mathrm{NH}_{4}$ additions (Fig. 8a-e), and is correlated with the decrease in $\mathrm{NH}_{4}$ to low or near zero concentrations. At $30 \mu \mathrm{mol} \mathrm{L}^{-1} \mathrm{NH}_{4}$ (Fig. 8e), $\mathrm{NO}_{3}$ drawdown is not observed even by the final day of the experiment. $\rho \mathrm{NO}_{3}$ (Fig. $8 \mathrm{f}-\mathrm{j}$ ) is progressively delayed with increasing $\mathrm{NH}_{4}$ concentration. However, the peak $\rho \mathrm{NO}_{3}$ increases with increasing $\mathrm{NH}_{4}$ concentration up to $20 \mu \mathrm{mol} \mathrm{L}^{-1}$, a result of the increased time for acceleration of the $\mathrm{NO}_{3}$ uptake rate. This increase in peak $\rho \mathrm{NO}_{3}$ at later times in the incubation allows all $\mathrm{NO}_{3}$ to be assimilated by Day 4 , the exception is at the $30 \mu \mathrm{mol} \mathrm{L}^{-1}$ where little $\mathrm{NO}_{3}$ uptake occurs even at that time.

\subsubsection{Enclosures from the Sacramento River ("WB09-1') experiment}

Enclosure experiments (WB09-1 series) were made with water collected from the Sacramento River, at Garcia Bend, above the
Sacramento Regional Waste Water Treatment Plant and at location RM44, below the Plant outfall. Three Garcia Bend experiments were conducted, one with no $\mathrm{N}$ amendments, a second with added $\mathrm{NH}_{4}$ and a third with added $\mathrm{NO}_{3}$. The RM44 enclosure was not amended. All enclosures were followed for 10 days. Daily samplings were made for nutrients and chlorophyll and for ${ }^{15} \mathrm{~N}$ tracer uptake rate measurements at 50\% ambient light.

The time series of modeled $\mathrm{N}$ concentration and uptake (with $\alpha=8 \times 10^{-5} \mathrm{~h}^{-2}$ ) and measured data are show in Fig. 9a-h. The un-amended Garcia Bend enclosure time series of $\mathrm{NO}_{3}$ and $\mathrm{NH}_{4}$ drawdown (Fig. 9a) is very similar to the low $\mathrm{NH}_{4}$, high $\mathrm{NO}_{3}$ enclosure using Central Bay water (Fig. 7a). With added $\mathrm{NH}_{4}$ to Garcia Bend water (Fig. 9c) modeled $\mathrm{NO}_{3}$ and $\mathrm{NH}_{4}$ drawdown are delayed similar to the pattern in the manipulated Central Bay enclosure with $5 \mu \mathrm{mol} \mathrm{L}^{-1} \mathrm{NH}_{4}$ added (Fig. 8b), and also very similar to the RM44 enclosure (Fig. 9g) which had elevated initial $\mathrm{NH}_{4}$ and $\mathrm{NO}_{3}$. The modeled $\mathrm{NO}_{3}$ in the $\mathrm{NO}_{3}$ amended Garcia Bend enclosure (Fig. 9e) was exhausted one day earlier than was observed in the enclosure. 
a

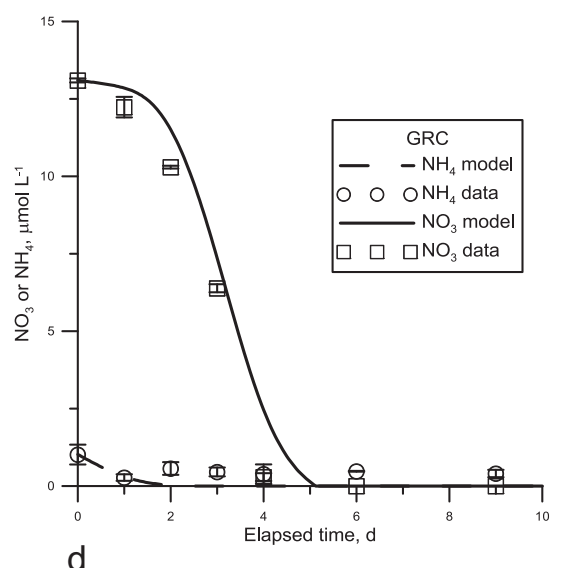

d
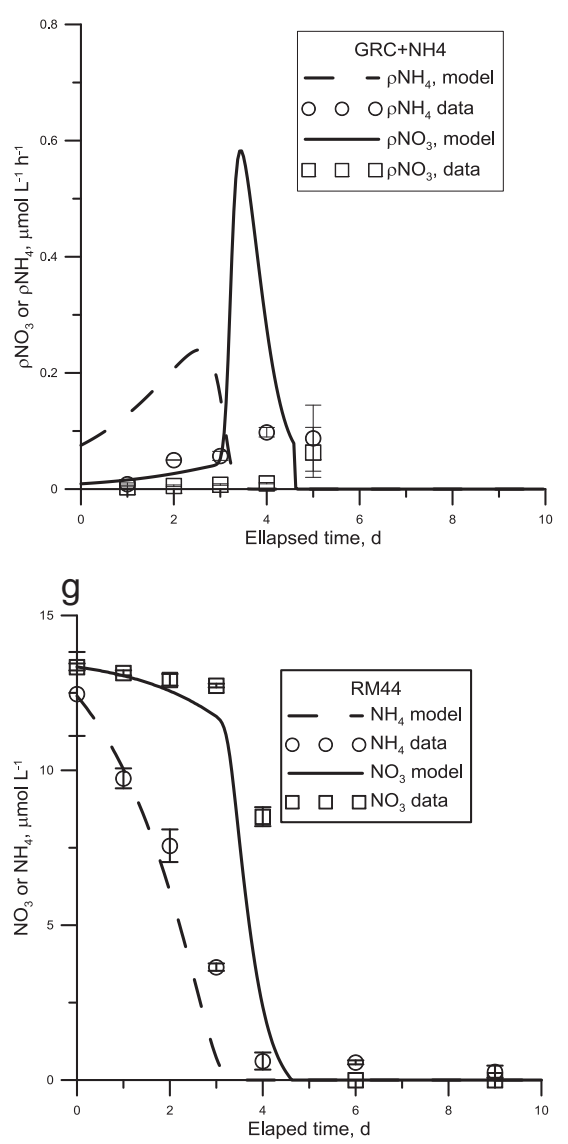

b
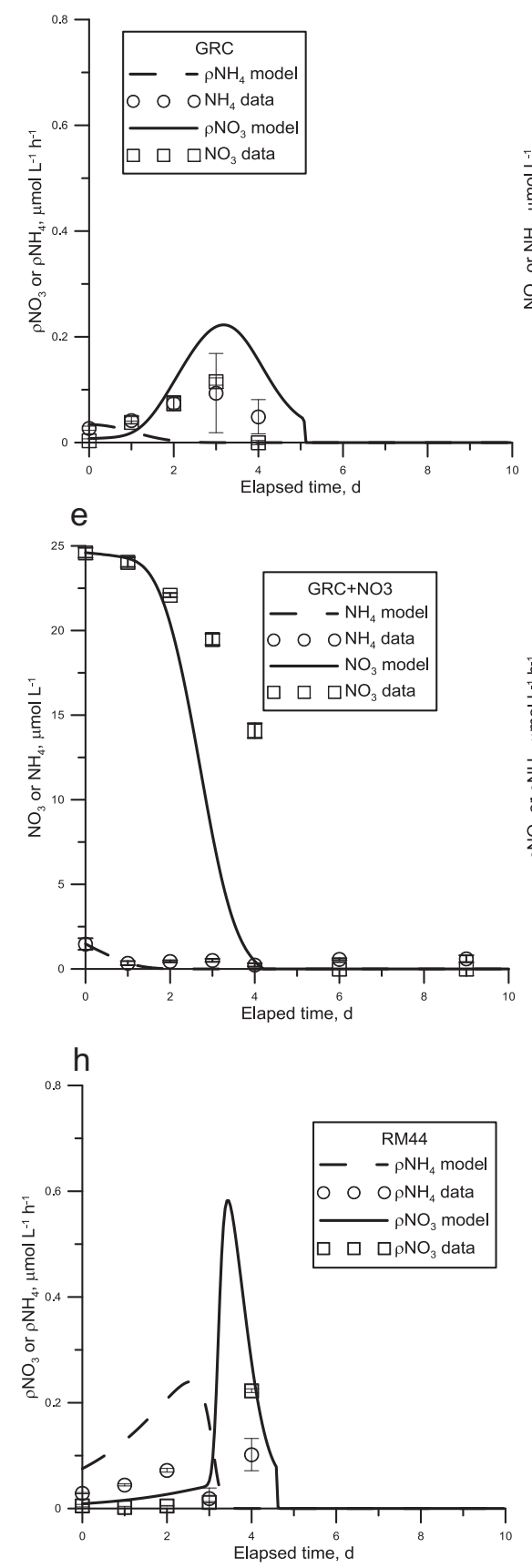

C
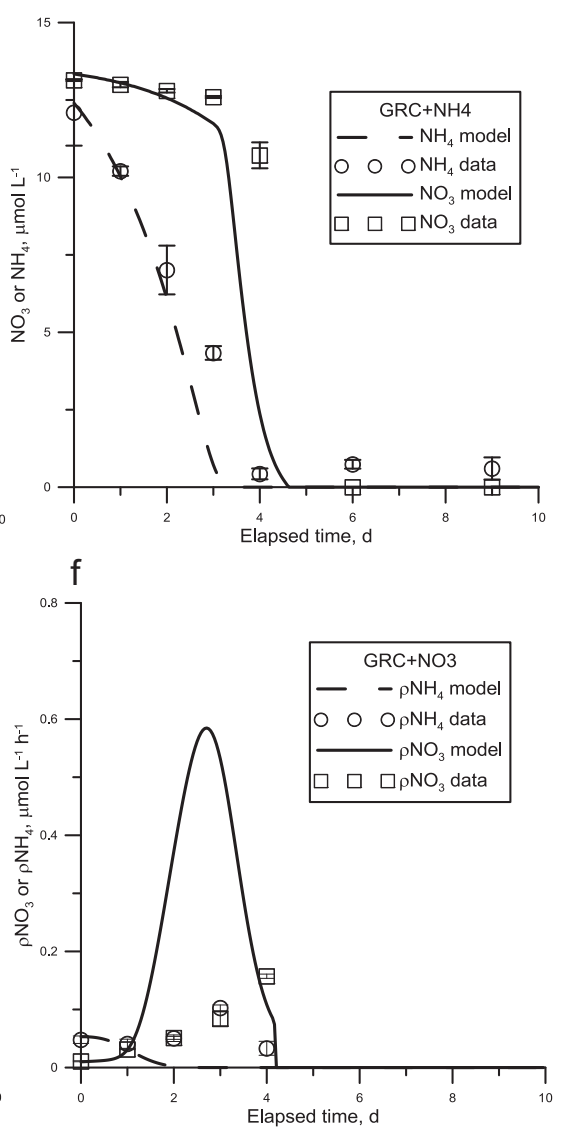

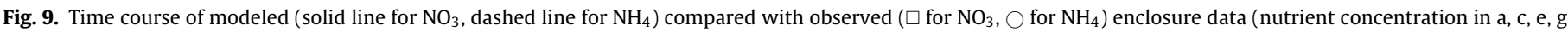

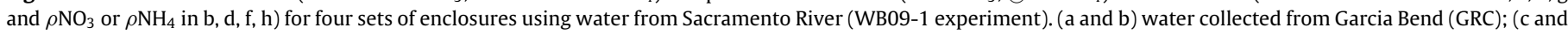
d) water collected from Garcia Bend with added $\mathrm{NH}_{4}$; (e and f) water collected from Garcia Bend with added $\mathrm{NO}_{3}$, ( $\mathrm{g}$ and h) water collected from location RM44.

In the two high $\mathrm{NH}_{4}$ enclosures, $\rho \mathrm{NH}_{4}$ as modeled overestimated the measured uptake rates (Fig. $9 \mathrm{~d}$ and $\mathrm{h}$ ), but the agreement between time series of modeled and observed $\mathrm{NH}_{4}$ concentrations (Fig. 9c and g) suggests the measured ${ }^{15} \mathrm{~N}$ uptake data may be in error. Modeled $\rho \mathrm{NO}_{3}$ was in good agreement with measured rates in the un-amended Garcia Bend and RM44 enclosures (Fig. 9b and h), but were higher than measured uptake in the two amended enclosures (Fig. 9d and f) suggesting a problem with the ${ }^{15} \mathrm{~N}$ measurements. In the case of the $\mathrm{NO}_{3}$ amended Garcia Bend enclosure (Fig. 9e and f) the modeled increase in $\rho \mathrm{NO}_{3}$ due to shift-up (acceleration) by increased $\mathrm{NO}_{3}$ did not occur in the measured enclosure results. The measured peak in $\rho \mathrm{NO}_{3}$ in the enclosure would have occurred after 4 days, as $\mathrm{NO}_{3}$ was drawn down in the enclosure (Fig. 9e). However no uptake measurements with ${ }^{15} \mathrm{NO}_{3}$ were made at that time.

\subsubsection{Enclosures from the northern Estuary ("Bad Suisun 3“) experiment}

A set of enclosures with water collected in Central Bay, Suisun Bay, Rio Vista in the Sacramento River and at Ward Island in the lower San Joaquin River (Fig. 1) were sampled daily as in the previous experiments. Concentrations and uptake of $\mathrm{NH}_{4}$ and $\mathrm{NO}_{3}$ are plotted against elapsed time in Fig. 10a-h. Modeled drawdown of $\mathrm{NH}_{4}$ and measured data (Fig. 10a, c, e and g) are in very good 

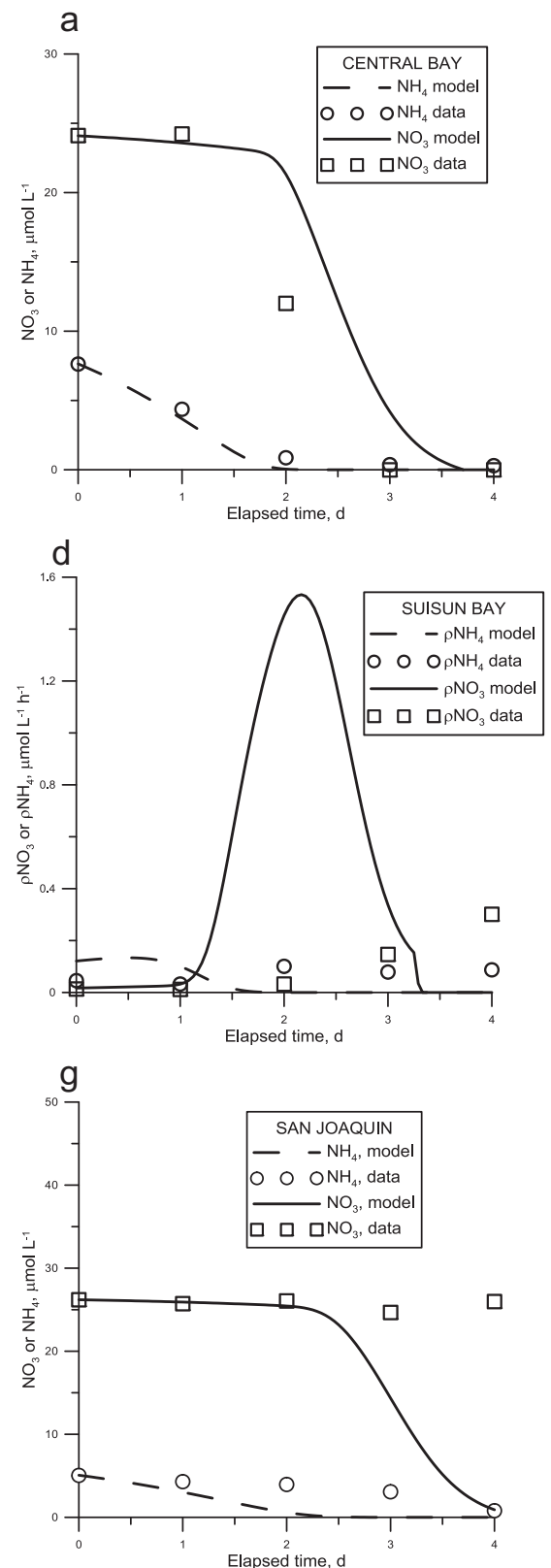
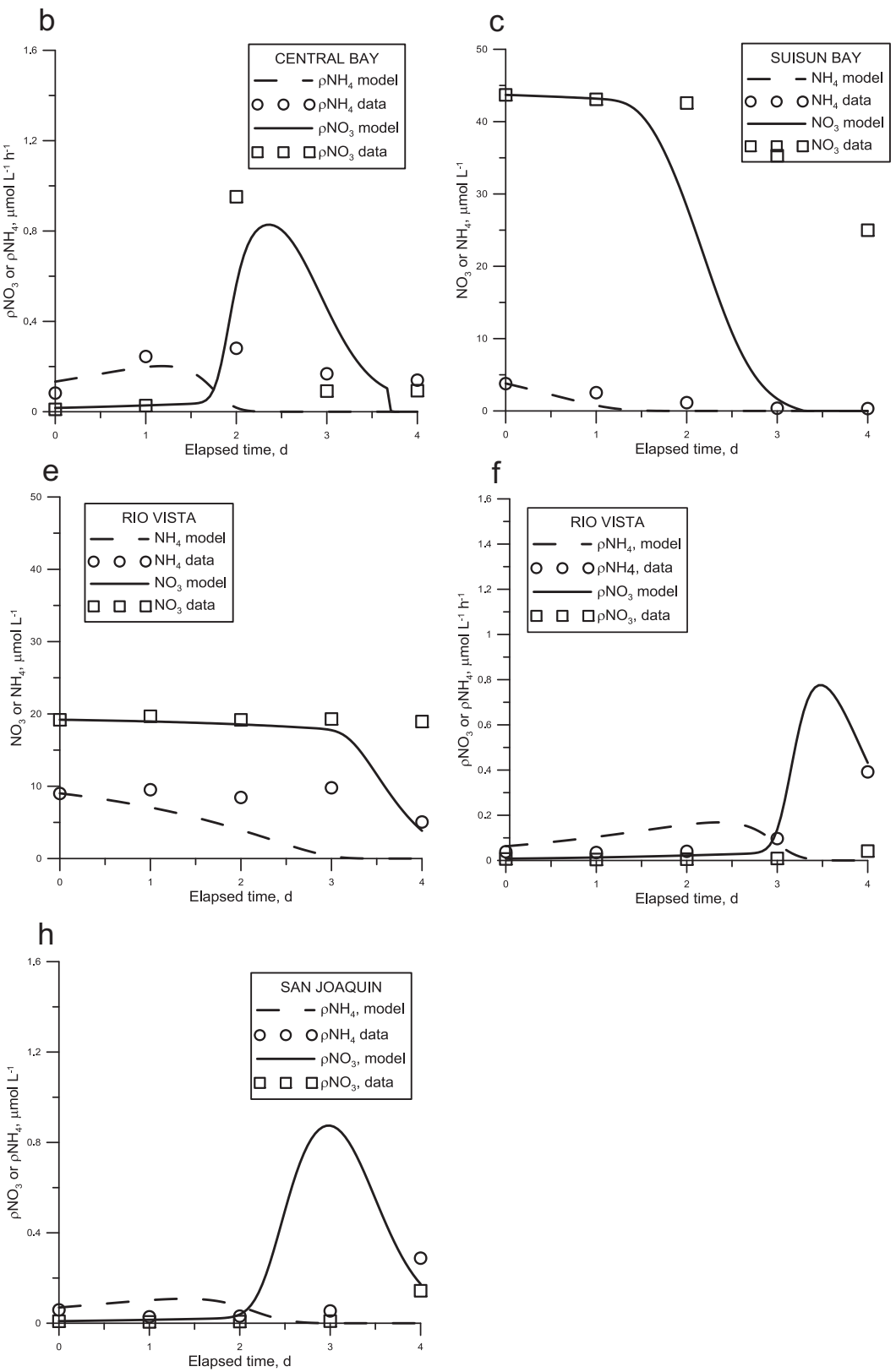

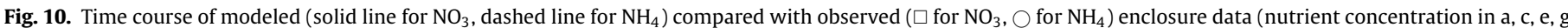

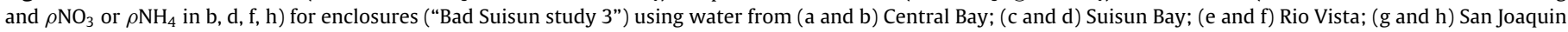
River.

agreement with Central Bay and Suisun Bay (Fig. 10a and c) but not for Rio Vista and San Joaquin (Fig. 10e and g) where no change in $\mathrm{NH}_{4}$ occurred until Day 4 in the enclosures. The timing of modeled $\mathrm{NO}_{3}$ decline in the Central Bay enclosure was slower than the measured data, but measured pattern is correct (Fig. 10a). The modeled peak and timing of $\rho \mathrm{NO}_{3}$ in Central Bay (Fig. 10b) are in agreement during the first two days, but measured $\rho \mathrm{NO}_{3}$ in Days 3 and 4 when the $\mathrm{NO}_{3}$ concentrations were zero was likely an artifact of the added $\mathrm{NO}_{3}$ substrate as part of the ${ }^{15} \mathrm{~N}$ inoculation.

Modeled $\mathrm{NH}_{4}$ decline and observed data are in agreement in the Suisun Bay enclosure (Fig. 10c). However, measured $\mathrm{NO}_{3}$ declined more slowly than modeled results. Modeled $\rho \mathrm{NH}_{4}$ is higher than data in the first two days (Fig. 10d). The measured $\mathrm{NH}_{4}$ uptake rates after Day 2 are higher than modeled, again, likely due to the $\mathrm{NH}_{4}$ substrate enhancement from ${ }^{15} \mathrm{~N}$ additions at low $\mathrm{NH}_{4}$ concentrations. The modeled peak in $\rho \mathrm{NO}_{3}$ at low $\mathrm{NH}_{4}$ concentrations (Fig. 10d) was not observed in the data, where $\mathrm{NO}_{3}$ uptake begins to increase in the last two days, as $\mathrm{NO}_{3}$ concentrations in the enclosures begins to decrease. Some unknown factor appears to be selectively depressing $\mathrm{NO}_{3}$ uptake in the Suisun Bay enclosure (Parker et al., 2012a). Trace metal leakage from paint from a large number of anchored naval ships (the U.S. Naval Reserve or "mothball fleet") is one possibility (NOAA Office of Response and Restoration, 2009). Herbicides applied for agricultural weed control and marsh restoration are also sources of toxicity (Blaser et al., 2011; Blaser, 2012).

At Rio Vista, the disparity in $\mathrm{NO}_{3}$ uptake between model output and measured data (Fig. 10f) is even more severe than in the Suisun Bay enclosure (Fig. 10d). $\mathrm{NH}_{4}$ concentration drawdown is delayed until the end of the experiment, while modeled $\mathrm{NH}_{4}$ concentration declines throughout the enclosure period and reaches zero after Day 3 enabling $\mathrm{NO}_{3}$ decline (Fig. 10e). However, the data show no decline in $\mathrm{NO}_{3}$ throughout the experiment. Measured $\rho \mathrm{NO}_{3}$ 

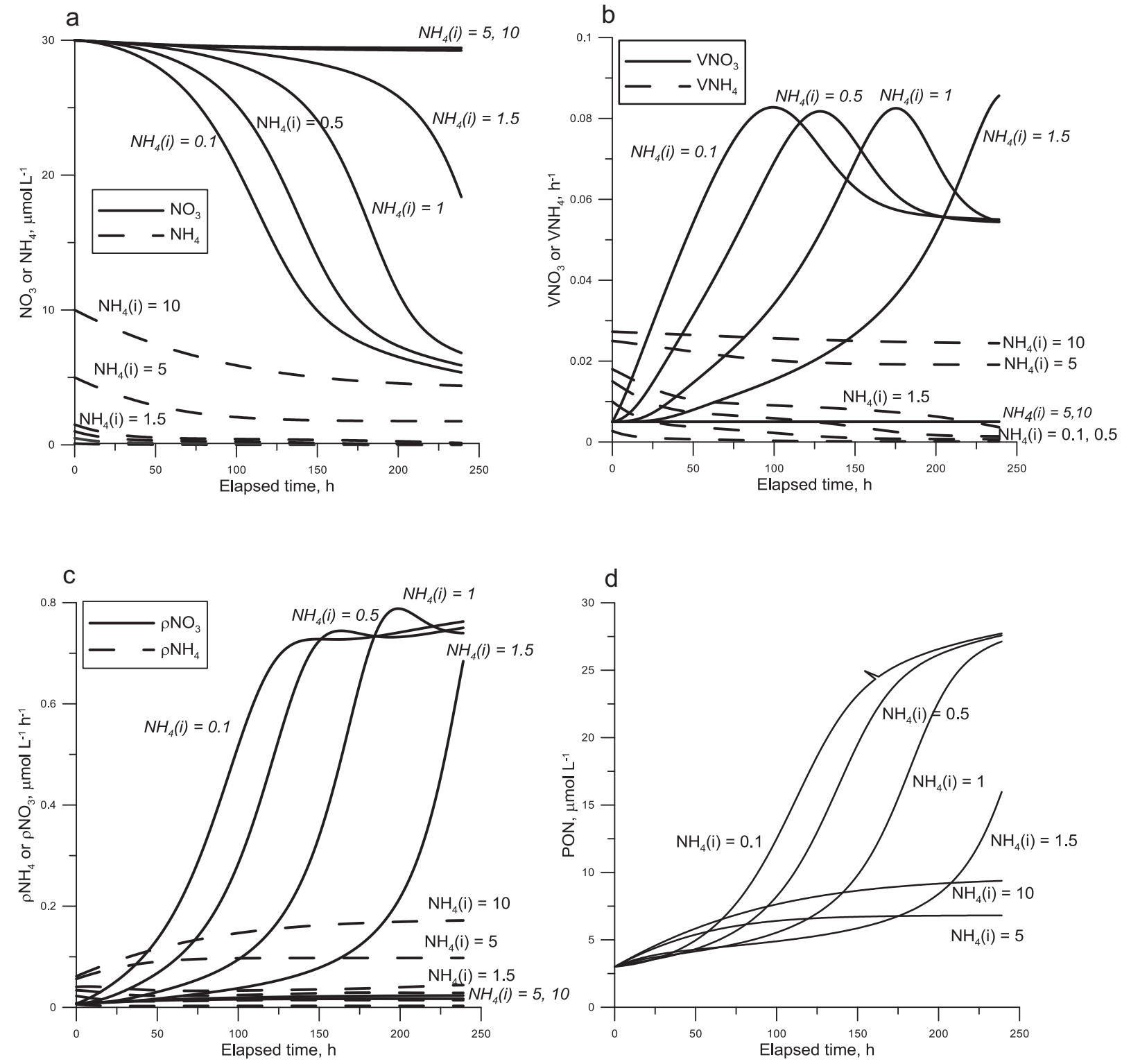

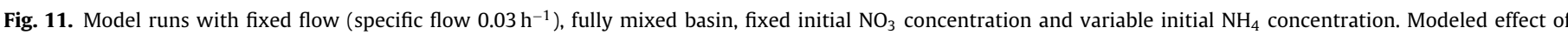

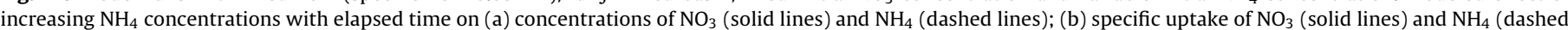

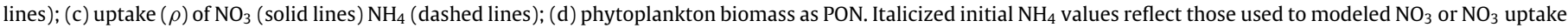
responses.

and $\rho \mathrm{NH}_{4}$ (Fig. 10f) are nearly zero during the first two days and increase slightly toward the end of the time series. The expected peak in $\mathrm{NO}_{3}$ uptake was not observed as $\mathrm{NO}_{3}$ uptake rates remained almost zero throughout.

The patterns observed in the San Joaquin River enclosure (Fig. $10 \mathrm{~g}$ ) most resemble those of the Rio Vista enclosure, with slow $\mathrm{NH}_{4}$ decline and no $\mathrm{NO}_{3}$ drawdown (Fig. 10e) low uptake of $\mathrm{NH}_{4}$ and virtually no $\mathrm{NO}_{3}$ uptake (Fig. $10 \mathrm{~h}$ ) all in comparison with the modeled patterns. Comparison of these model simulations with enclosure data provides the basis for moving on to the next level of model with freshwater flow to simulate Suisun Bay.

\section{Model runs with freshwater flow}

\subsection{Model runs with fixed flow, in fully mixed basin mode, with variable $\mathrm{NH}_{4}$ inflow}

The model was run at a fixed specific flow rate of $0.03 \mathrm{~h}^{-1}$, essentially a dilution rate (Flow/Volume) and in this mode represents a hypothetical bay of $1 \mathrm{~m}^{3}$ volume or any multiple thereof keeping Flow/Volume $=0.03$. The model was run with six $\mathrm{NH}_{4}$ concentrations from 0.1 to $10 \mu \mathrm{mol} \mathrm{L}^{-1}$; other parameters as in the non-flow model runs. After $240 \mathrm{~h}$, (10 days) the development of a phytoplankton bloom, simulated by turning on irradiance with a fully mixed water column and a uniform vertical light field is shown in Fig. 11a-d. The same basic sequence shown in the enclosure model runs and data occurs with a decline in $\mathrm{NO}_{3}$ after a decline in $\mathrm{NH}_{4}$ concentration to low, near zero values (Fig. 11a). $\mathrm{NO}_{3}$ is drawn down to concentrations of $5-7 \mu \mathrm{mol} \mathrm{L}^{-1}$ within 10 days, except at the highest $\mathrm{NH}_{4}$ concentrations ( 5 and $10 \mu \mathrm{mol} \mathrm{L}^{-1}$ ) when no drawdown occurs within the 10 day $(240 \mathrm{~h}$ ) period (Fig. 11a), a consequence of the continued elevated $\mathrm{NH}_{4}$ concentrations at these two highest initial $\mathrm{NH}_{4}$ inputs.

Specific $\mathrm{NO}_{3}$ uptake, $\mathrm{VNO}_{3}$, increases with elapsed time (Fig. 11b); however, the peak in $\mathrm{VNO}_{3}$ is delayed at higher inflowing concentrations of $\mathrm{NH}_{4}$ up to $1.5 \mu \mathrm{mol} \mathrm{L}^{-1}$ and then $\mathrm{VNO}_{3}$ falls to nearly zero at $\mathrm{NH}_{4}$ concentrations of $5.0 \mu \mathrm{mol} \mathrm{L}^{-1}$ and greater. $\mathrm{VNH}_{4}$ increases with greater inflowing concentrations of $\mathrm{NH}_{4}$ 
according to the Michaelis-Menten kinetics built into the model, but shows no increase with time and remains well below the peak values of $\mathrm{VNO}_{3}$ (Fig. 11b).

$\mathrm{NNO}_{3}$ (Fig. 11c), follows closely that of $\mathrm{VNO}_{3}$ with peak values delayed and increasing as $\mathrm{NH}_{4}$ concentrations increase and falling to zero at initial $\mathrm{NO}_{3}$ concentrations of $5.0 \mu \mathrm{mol} \mathrm{L}^{-1}$ or greater. $\rho \mathrm{NH}_{4}$ uptake (Fig. 11c) increases with time, even as the $\mathrm{VNH}_{4}$ declines, due to the increasing PON biomass. Increases in PON are delayed with increasing inflowing $\mathrm{NH}_{4}$ concentrations (Fig. 10d).

With inflowing $\mathrm{NH}_{4}$ up to $1 \mu \mathrm{mol} \mathrm{L}^{-1}$ a maximum biomass (as PON) of $\sim 30 \mu \mathrm{mol} \mathrm{L}^{-1}$ is achieved after 10 days $(240 \mathrm{~h})$ and is based primarily on the assimilation of $\mathrm{NO}_{3}$ (Fig. 11d). At inflowing $\mathrm{NH}_{4}$ of $\geq 5 \mu \mathrm{mol} \mathrm{L}^{-1}$ PON only reaches $<10 \mu \mathrm{mol} \mathrm{L}^{-1}$ (Fig. $11 \mathrm{~d}$ ). These plots show clearly the two states of a modeled bay phytoplanktonnitrogen ecosystem, with most inflowing $\mathrm{NO}_{3}$ exported unused when $\mathrm{NH}_{4}$ concentrations are higher, $\geq 5 \mu \mathrm{mol} \mathrm{L}^{-1}$ (Fig. 11a). Fig. 11d shows PON accumulation occurs when $\mathrm{NO}_{3}$ is accessed (Fig. 11c) and $\mathrm{NH}_{4}$ is low (i.e. $\mathrm{NH}_{4}<1 \mu \mathrm{mol} \mathrm{L}^{-1}$ ) in contrast to low PON accumulation with $\mathrm{NH}_{4} \geq 5 \mu \mathrm{mol} \mathrm{L}^{-1}$.). Intermediate conditions are described by the model with $\mathrm{NH}_{4}$ of 1 to $5 \mu \mathrm{mol} \mathrm{L}^{-1}$. PON produced from $\mathrm{NH}_{4}$ uptake increases with increased $\mathrm{NH}_{4}$ concentrations, but much less than the levels based on $\mathrm{NO}_{3}$ We ascribe this condition to the $\mathrm{NH}_{4}$ paradox (Dugdale et al., 2012). An illustration of how this can be extended to field conditions uses data from Central Bay (next to the Golden Gate). This SFE ecosystem in summer has an $\mathrm{NH}_{4}$ concentration of $5.3 \mu \mathrm{mol} \mathrm{L}-1$ (Wilkerson et al., 2006). The model would predict the phytoplankton biomass as PON to be $7 \mu \mathrm{mol} \mathrm{L}^{-1}$, according to the $\mathrm{NH}_{4}$ curve for $\mathrm{NH}_{4}(\mathrm{i})=5 \mu \mathrm{mol} \mathrm{L}^{-1}$ in Fig. $11 \mathrm{~d}$. The average measured PON was $10.2 \mu \mathrm{mol} \mathrm{L}^{-1}$. This is the low PON accumulation state. As a consequence, even though $\mathrm{NO}_{3}$ concentrations are high in the summer in Central Bay (34.4 $\mu \mathrm{mol} \mathrm{L}^{-1}$; Wilkerson et al., 2006) they are not used and the potential source of $\mathrm{N}$ for fueling productivity is exported to the ocean. Other estuaries with high $\mathrm{NH}_{4}$ inputs may exhibit this condition (i.e. unused $\mathrm{NO}_{3}$ ) predicted by the model.

\subsection{Model runs with variable flow, in fully mixed basin mode, with fixed $\mathrm{NH}_{4}$ inflow concentrations}

As flow is introduced into the model a boundary can be observed where the phytoplankton-nutrient system state drops into the $\mathrm{NH}_{4}$ based, low biomass, low productivity state (Fig. 12) at specific flows (i.e. flow normalized to the volume of a bay, i.e. $=F / V$ ) of $0.01-0.02 \mathrm{~h}^{-1}$ depending upon the initial $\mathrm{NH}_{4}$ conditions. The critical flow for a productivity system change is higher at lower $\mathrm{NH}_{4}$ concentrations. Above this critical flow rate, there is insufficient residence time available for the assimilation and reduction of $\mathrm{NH}_{4}$ to levels allowing phytoplankton $\mathrm{NO}_{3}$ uptake and PON accumulation.

4.3. Model runs with variable flow, fully mixed water column, with depth-integration allowing for light limitation

Model runs using estimates of depth-integrated $\mathrm{NO}_{3}$ and $\mathrm{NH}_{4}$ uptake were made at flows from 100 to $2000 \mathrm{~m}^{3} \mathrm{~s}^{-1}$ and inflowing concentrations of $\mathrm{NH}_{4}$ from 1 to $10 \mu \mathrm{mol} \mathrm{L}^{-1}$. Parameters were the same as in previous model run modes (Sections 4.1 and 4.2) however, $\mathrm{NO}_{3}$ and $\mathrm{NH}_{4}$ uptakes were estimated for the euphotic zone assuming that a single, light-saturated (i.e. $50 \%$ of surface irradiance) uptake rate was representative for the euphotic zone. The euphotic zone depth $(1.05 \mathrm{~m})$ was calculated from a mean Suisun Secchi depth of $0.3 \mathrm{~m}$ (Wilkerson et al., 2006) and the empirical relationship between Secchi depth and light attenuation coefficient as determined for Suisun Bay by Kimmerer et al. (2012). The euphotic zone $\mathrm{N}$ uptake was scaled to the ratio of the euphotic zone depth to the mean depth of Suisun Bay $(5.61 \mathrm{~m})$ and provided in

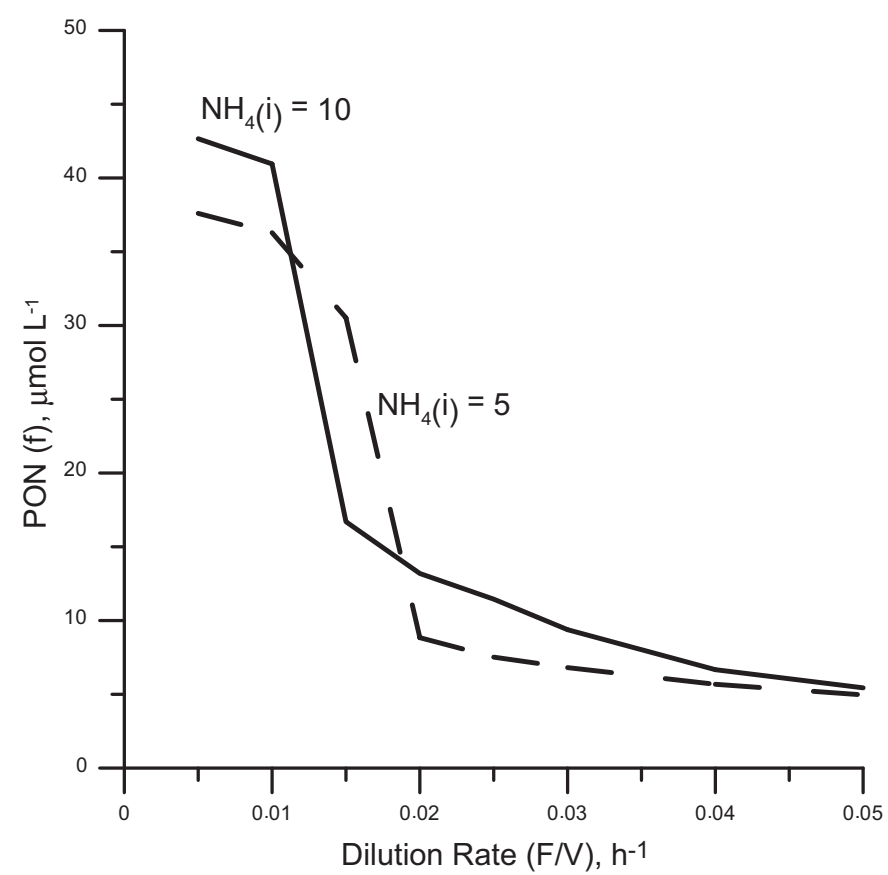

Fig. 12. Model runs with varying flow, in fully mixed basin mode with fixed $\mathrm{NH}_{4}$ inflow concentrations. Effect of variable specific flow rate $\left(F / V, \mathrm{~h}^{-1}\right)$ and initial $\mathrm{NH}_{4}$ of 5 or $10 \mu \mathrm{mol} \mathrm{L}^{-1}$ on the final PON concentration resulting after $240 \mathrm{~h}$.

these runs as depth-integrated $\mathrm{N}$ uptake values. Model runs were made for 30 days. Final values of PON are contoured in Fig. 13 on a $\mathrm{NH}_{4}$-flow plane. These contours show the two state ecosystem with a sharp transition from high, $\mathrm{NO}_{3}$ based productivity (i.e.

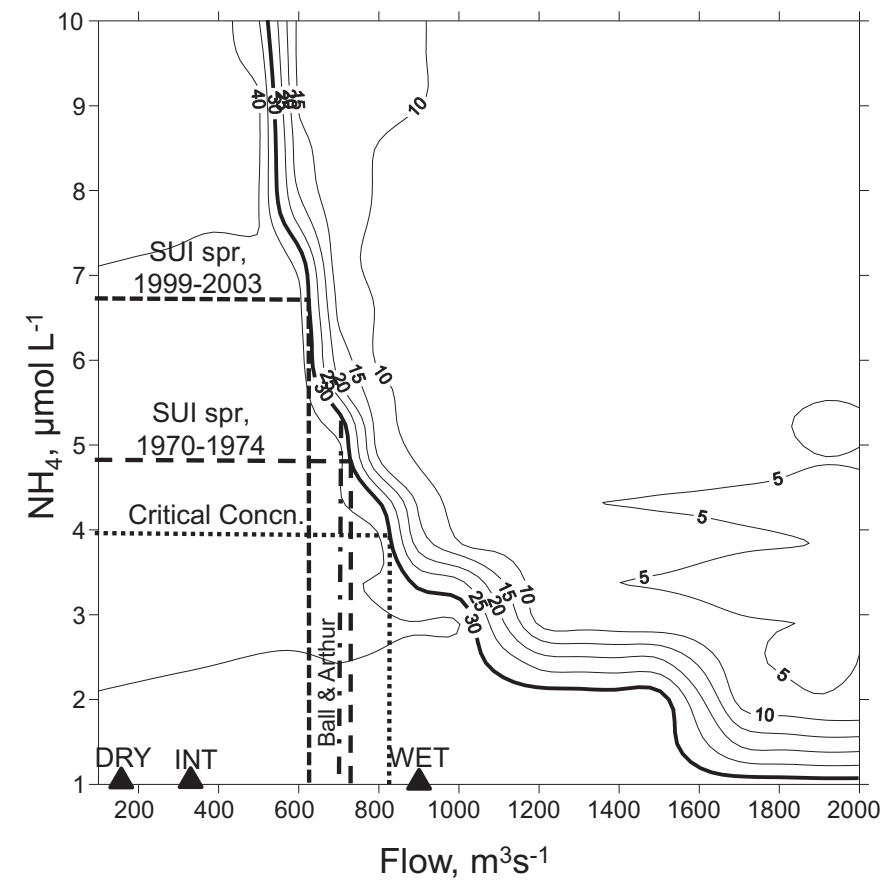

Fig. 13. Model runs with varying flow a fully mixed water column, with depthintegration allowing for light limitation. Effect of flow and initial $\mathrm{NH}_{4}$ concentrations on final PON concentrations (in $\mu \mathrm{mol} \mathrm{L}^{-1}$ as contours with $30 \mu \mathrm{g} \mathrm{L}^{-1}$ in bold). Arrows show flows in dry, intermediate and wet water years from Peterson et al. (1985). Horizontal dashed lines plotted are mean $\mathrm{NH}_{4}$ concentrations (for spring 1970-1974 and 1999-2003) or criterion extended to the $30 \mu \mathrm{g} \mathrm{L}^{-1}$ contour and projected to the flow axis ( $x$-axis). The Ball and Arthur (1979) vertical line is set at the maximum flow at which chlorophyll blooms were observed. 
high PON concentrations) to low, $\mathrm{NH}_{4}$ based productivity (i.e. low phytoplankton biomass) delineated by the $30 \mu \mathrm{mol} \mathrm{L}^{-1}$ PON contour. At high $\mathrm{NH}_{4}$ concentrations (5-10 $\mu \mathrm{mol} \mathrm{L}^{-1}$ ) the contour lines are nearly vertical and small changes in flow result in a transition from one productivity state to the other. High $\mathrm{NH}_{4}$ concentrations restrict the maximum flow to $\sim 600 \mathrm{~m}^{3} \mathrm{~s}^{-1}$ for high productivity. Changes in $\mathrm{NH}_{4}$ concentration have far less effect than flow in this region. Below $\mathrm{NH}_{4}$ of $5 \mu \mathrm{mol} \mathrm{L}^{-1}$, the critical flow increases with decreasing $\mathrm{NH}_{4}$ concentration to about $2 \mu \mathrm{mol} \mathrm{L}^{-1}$ where the contours are horizontal and small changes in $\mathrm{NH}_{4}$ concentration can result in a state transition; flow is less important than $\mathrm{NH}_{4}$ in this region. In summary, low $\mathrm{NH}_{4}$ concentrations allow higher flows for the high productivity (biomass) condition (up to $1500 \mathrm{~m}^{3} \mathrm{~s}^{-1}$ ) and are more important than flow in this region for determining productivity condition.

\section{Discussion}

\subsection{Comparison of no-flow model results with enclosure experiments}

The model when run in the no-flow mode provides a diagnostic tool for interpretation of enclosure experimental data, offering mechanisms for phytoplankton and $\mathrm{N}$ interactions and suggesting next steps in understanding anomalous phytoplankton environmental conditions in the field. In some situations, modeled responses of $\mathrm{NH}_{4}$ and $\mathrm{NO}_{3}$ uptake and $\mathrm{N}$ drawdown agreed well with field data from a variety of enclosure experiments using water sampled from estuarine locations other than the location originally used to calibrate the model (i.e. Central Bay). In others, comparison of modeled results with data revealed conditions where patterns of phytoplankton uptake of $\mathrm{NH}_{4}$ or $\mathrm{NO}_{3}$ and biomass accumulation did not agree with the model. For example, the enclosures filled with water from Rio Vista (Fig. 10e) showed relatively slow $\mathrm{NH}_{4}$ drawdown compared to modeled expectations, accompanied by delayed $\mathrm{NO}_{3}$ drawdown, suggesting a growth-limited condition. These anomalous conditions that do not fit our modeled view of $\mathrm{NH}_{4}$ and $\mathrm{NO}_{3}$ interaction, are likely due to other parameters in the water, such as dominance by species other than diatoms and factors that directly affect $\mathrm{N}$ uptake and growth, e.g. herbicides (Blaser, 2012). Similar observations were made by Parker et al. (2012a,b) in experimental enclosures filled with water from a station in western Suisun Bay. The Suisun Bay enclosure (Fig. 10c) showed typical $\mathrm{NH}_{4}$ drawdown but slow $\mathrm{NO}_{3}$ drawdown compared to model results, suggesting a problem specific to $\mathrm{NO}_{3}$ uptake, possibly unknown toxins affecting $\mathrm{NO}_{3}$ transporters or the enzyme nitrate reductase. The usefulness of the model in these two cases is to provide suggestions for appropriate experiments, such as Toxicity Identification Evaluations (TIE's) (e.g. US EPA, 1988) to isolate the specific problem causing the observed effects.

\subsection{Comparison of with-flow model results with historical conditions}

Phytoplankton blooms in Suisun Bay prior to 1987 were accompanied by complete drawdown of initial $\mathrm{NH}_{4}$ and $\mathrm{NO}_{3}$. Using data collected from 1969 to 1977 Ball and Arthur (1979) observed DIN to decline in the summer in Suisun Bay, to limiting concentrations, $<0.02 \mathrm{mg} \mathrm{N} \mathrm{L}^{-1}\left(1.4 \mu \mathrm{mol} \mathrm{L}^{-1}\right)$ with peak summer concentrations of chlorophyll of $40-100 \mu \mathrm{g} \mathrm{L}^{-1}$. Similarly, this was observed in Honker Bay (in Suisun Bay, Fig. 1) in 1970 by Di-Toro et al. (1977, their Fig. 13) who reported $\mathrm{NH}_{4}$ concentrations to decline from $0.07 \mathrm{mg} \mathrm{L}^{-1}\left(5.0 \mu \mathrm{mol} \mathrm{L}^{-1}\right)$ in May to undetectable in July and $\mathrm{NO}_{3}$ from $0.4 \mathrm{mg} \mathrm{L}^{-1}\left(28.6 \mu \mathrm{mol} \mathrm{L}^{-1}\right)$ to undetectable in July, when chlorophyll concentrations reached $50 \mu \mathrm{g} \mathrm{L}^{-1}$. These pre-1987 blooms were supported by both $\mathrm{NH}_{4}$ and $\mathrm{NO}_{3}$ and were in the high biomass, $\mathrm{NO}_{3}$ utilization state analogous to the high biomass state predicted by the SFE biogeochemical flow model, i.e. in the area of Fig. 13, to the left of the $30 \mu \mathrm{g} \mathrm{L}^{-1}$ PON contour.

The mean spring $\mathrm{NH}_{4}$ concentration for the years 1970-1974 (SUI spr. 1970-1974 in Fig. 13) in Suisun Bay (Station D6) of $4.95 \pm 1.49 \mu \mathrm{mol} \mathrm{L}^{-1}$ (Ball, 1977) is plotted on the y-axis of Fig. 13. A horizontal line dawn from this $\mathrm{NH}_{4}$ concentration intersects the $30 \mu \mathrm{g} \mathrm{L}^{-1}$ PON contour at a flow rate of $\sim 700 \mathrm{~m}^{3} \mathrm{~s}^{-1}$ (vertical line drawn to the $x$-axis), setting the maximum flow rate that would allow a high biomass bloom to occur. Ball and Arthur (1979) considered the Suisun Bay phytoplankton standing crop before 1976 to be related directly to water transparency and indirectly to Delta outflow (i.e. river flow) and concluded that only when the outflow varied between 110 and $700 \mathrm{~m}^{3} \mathrm{~s}^{-1}$ did chlorophyll concentrations of $>20 \mu \mathrm{g} \mathrm{L}^{-1}$ occur in the entrapment zone adjacent to the shallows of Suisun/Honker Bay, the same maximum flow predicted by the model for the mean $\mathrm{NH}_{4}$ concentration.

\subsection{Comparison of with-flow model results with contemporary conditions}

More recently (1999-2003) the mean spring $\mathrm{NH}_{4}$ concentration in Suisun Bay was $6.8 \mu \mathrm{mol} \mathrm{L}^{-1}$ (Wilkerson et al., 2006) which intersects the $30 \mu \mathrm{mol} \mathrm{L}^{-1}$ PON contour near $600 \mathrm{~m}^{3} \mathrm{~s}^{-1}$ (Fig. 13), setting an upper flow limit for high biomass accumulation slightly lower than the prediction from the pre-1987 data $\left(\sim 700 \mathrm{~m}^{3} \mathrm{~s}^{-1}\right)$. Another prediction of the maximum flow rate for bloom formation is obtained by plotting the $4 \mu \mathrm{mol} \mathrm{L}^{-1} \mathrm{NH}_{4}$ concentration criterion below which $\mathrm{NO}_{3}$ uptake occurs and bloom formation begins (Dugdale et al., 2012) on the $y$-axis of Fig. 13, yielding a maximum flow rate of just over $800 \mathrm{~m}^{3} \mathrm{~s}^{-1}$.

Over the range of $\mathrm{NH}_{4}$ concentrations from 4.0 to $6.8 \mu \mathrm{mol} \mathrm{L}^{-1}$, predicted maximum river flow rates range narrowly from 600 to $800 \mathrm{~m}^{3} \mathrm{~s}^{-1}$ in good agreement with the maximum river flow, $700 \mathrm{~m}^{3} \mathrm{~s}^{-1}$ suggested by Ball and Arthur (1979). Two large blooms were observed in Suisun Bay from mid-April to the end of May 2010. The mean Delta Outflow during that period was $644.5 \pm 113.9 \mathrm{~m}^{3} \mathrm{~s}^{-1}$ just below the maximum flow $\left(700 \mathrm{~m}^{3} \mathrm{~s}^{-1}\right)$ described by Ball and Arthur (1979), and also below the modeled estimate of maximum flow $\left(800 \mathrm{~m}^{3} \mathrm{~s}^{-1}\right)$ for the $4 \mu \mathrm{mol} \mathrm{L}^{-1} \mathrm{NH}_{4}$ concentration criterion. The mean Delta Outflow 2010 flow during the bloom period was also below the washout flow criterion of $1100 \mathrm{~m}^{3} \mathrm{~s}^{-1}$ calculated by Dugdale et al. (2012), above which phytoplankton populations are washed out and cannot bloom. This washout criterion is based on the mean spring $\mathrm{NH}_{4}$ uptake rate of the phytoplankton in Suisun Bay (Dugdale et al., 2012) and above that flow rate, the growth rate of the phytoplankton is less than the loss rate due to flow and the population is washed out and shows zero growth or net loss.

In addition to $\mathrm{NH}_{4}$ and flow impacts on phytoplankton blooms, grazing by invasive clams (Potamocorbula amurensis) could contribute to declining chlorophyll concentrations and lack of spring blooms although clams are in low concentration and size in spring (Greene et al., 2011). However, as discussed in Dugdale et al. (2012) clam abundance in Suisun Bay was unchanged in spring 2010, when there was a phytoplankton bloom, and were monitored at similar densities to previous years (in spring) when blooms were absent.

\subsection{Comparison of with-flow model results with wet versus dry years}

The mean river freshwater flows in spring for wet, intermediate and dry years (Peterson et al., 1985) are shown as arrow heads drawn on the $x$-axis. The model in its present form suggests that dry and intermediate years should allow phytoplankton blooms 
(i.e. $\mathrm{PON}>30 \mu \mathrm{mol} \mathrm{L}^{-1}$, equivalent to $\mathrm{chl}>30 \mu \mathrm{g} \mathrm{L}^{-1}$; Dugdale et al., 2012) at $\mathrm{NH}_{4}$ concentrations up to $10 \mu \mathrm{mol} \mathrm{L}^{-1}$. However, in wet years, $\mathrm{NH}_{4}$ concentrations would have to be $\leq 4 \mu \mathrm{mol} \mathrm{L}^{-1}$ for blooms to occur.

\subsection{Model predictions of spring bloom occurrences in Suisun Bay}

The similarity in freshwater flow relationship to phytoplankton blooms in Suisun Bay in the 1970s and recently in 2010, leads to the suggestion that the mechanism behind the earlier blooms was essentially the same as presently observed in Suisun Bay when $\mathrm{NH}_{4}$ concentrations are low (Wilkerson et al., 2006; Dugdale et al., 2007, 2012). This mechanism requires that phytoplankton be able to access the available $\mathrm{NO}_{3}$ for growth which does not happen when $\mathrm{NH}_{4}$ concentrations are high. The with-flow model results are consistent with this view. The model results are also consistent with the conclusion of Jassby (2008) that biomass accumulation is inversely related to freshwater flow, a consequence of reduced residence time with increased flow.

However, the model predicts high biomass with any concentration of $\mathrm{NH}_{4}$ up to $10 \mu \mathrm{mol} \mathrm{L}^{-1}$ and flows of less than $500 \mathrm{~m}^{3} \mathrm{~s}^{-1}$ (intersection of $10 \mu \mathrm{mol} \mathrm{L}^{-1} \mathrm{NH}_{4}$ with the $30 \mu \mathrm{g} \mathrm{L}^{-1} \mathrm{PON}$ ). Typically low flows would be expected in the summer. However, high levels of biomass do not occur in summer and have only been observed rarely in spring (i.e. Wilkerson et al., 2006; Dugdale et al., 2012). In the model any factor that reduces the rate at which $\mathrm{NH}_{4}$ concentrations decline or that add to the $\mathrm{NH}_{4}$ concentration will extend the period without $\mathrm{NO}_{3}$ uptake and prevent biomass accumulation. High rates of benthic regeneration of $\mathrm{NH}_{4}$, unaccounted-for sources of $\mathrm{NH}_{4}$ (e.g. waste water treatment plants) and high grazing rates by either benthos or zooplankton would have such an effect. None of these possibilities are considered in the present model. Clam biomass and grazing is highly seasonal and may be the most likely source of regenerated nitrogen as $\mathrm{NH}_{4}$ in summer and fall.

The model could be expanded in several ways. Both clam and zooplankton grazing could be added to the model in the near future. Exchange of $\mathrm{NH}_{4}$ with the sediment has been measured in Suisun Bay (J. Cornwell, personal communication) at rates that suggest it will be necessary to include this source/sink in the model. Pelagic nitrification $\left(\mathrm{NH}_{4}\right.$ oxidation to $\left.\mathrm{NO}_{3}\right)$ by bacteria and archaea has been estimated to be greater than phytoplankton $\mathrm{NH}_{4}$ uptake in the Sacramento River (Parker et al., 2012a,b) and consumes oxidation in the process of producing $\mathrm{NO}_{3}$. A nitrification pathway needs to be included in a future model. Then rates of nitrification measured with ${ }^{15} \mathrm{~N}$ (Parker, personal communication) should be compared to the model estimates. These enhancements to the model would provide a more complete description of the pattern of $\mathrm{NH}_{4}$ fluxes and concentrations with time. Other phytoplankton functional groups such as cyanobacteria could also be added. Ongoing studies of the effect of $\mathrm{NH}_{4}$ concentration and $\mathrm{N}$ :P ratio will provide data for validation of the enhanced model. Toxicity of $\mathrm{NH}_{4}$ to diatoms has not been included in the current model. However, $\mathrm{NH}_{4}$ inhibition of $\mathrm{NH}_{4}$ uptake by phytoplankton has been shown to occur in the Sacramento River when $\mathrm{NH}_{4}$ concentrations are $>20 \mu \mathrm{mol} \mathrm{L}^{-1}$. Such high concentrations of $\mathrm{NH}_{4}$ have not been observed in the source waters to Suisun Bay. To make the model functional for the Sacramento River such an inhibition term could be added.

\subsection{Future uses for the model}

The model results suggest that reduction in inflowing $\mathrm{NH}_{4}$ concentrations to Suisun Bay would reduce or eliminate the $\mathrm{NH}_{4}$ sensitivity of phytoplankton biogeochemical processes in the Bay. With these $\mathrm{NH}_{4}$ reductions, spring phytoplankton bloom occurrence would be dependent upon freshwater flow conditions, strongly improving the likelihood of blooms and food supply to pelagic organism decline species. On the other hand, proposed increases in freshwater flow, to provide more suitable habitat for the delta smelt, would be predicted to have no significant effect on phytoplankton productivity if $\mathrm{NH}_{4}$ concentrations were low, but could quite drastically reduce the biomass of phytoplankton at the present mean $\mathrm{NH}_{4}$ concentrations (e.g. $6.8 \mu \mathrm{mol} \mathrm{L}^{-1}$ in Suisun Bay) (Fig. 13).

The present model is one dimensional and nitrogen-based, and at this point should be regarded as a step in the development of a full three dimensional model of the SFE/Delta system. This tool will help elucidate the pre-1987 ecosystem processes and evaluate the impact of management and regulatory strategies. A unique aspect of the present model is the inclusion of terms for the time varying rate of maximum $\mathrm{NO}_{3}$ uptake as a function of $\mathrm{NO}_{3}$ concentration (acceleration) and for inhibition of $\mathrm{NO}_{3}$ uptake by $\mathrm{NH}_{4}$. The model of Di-Torro et al. (1977) included a mechanism for considering preferential use of $\mathrm{NH}_{4}$ and $\mathrm{NO}_{3}$ uptake by estuarine phytoplankton, ensuring that $\mathrm{NH}_{4}$ is used before $\mathrm{NO}_{3}$. However, the likely role of $\mathrm{NH}_{4}$ in creating a stable two-state productivity (biomass) ecosystem and modulating the flow-bloom pattern in Suisun Bay has not been considered before. The modeled phytoplankton biomass in the two states of Suisun Bay may be analogous to previously existing ecosystem states of the SFE described by Glibert et al. (2011). The modeled high biomass, $\mathrm{NO}_{3}$ based, high productivity state would be analogous to the pre-1982, diatom era with large copepods (Eurytemora) and delta smelt (Glibert et al., 2011). The modeled low biomass, low productivity state based on $\mathrm{NH}_{4}$ would be analogous to the post 1982 cryptophyte/flagellate era with small copepods (Pseudodiaptomus) with bass and shad. Glibert et al. (2011) attribute the change in food web components to the shift in the dominant form of DIN, $\mathrm{NH}_{4}$ becoming more dominant post 1982 .

The model can be improved and extended with the addition of grazing terms, and chemical transformations (e.g. nitrification) as discussed. Such an improved version of this relatively simple, validated model could be embedded into three dimensional biogeochemical models under construction for the SFE and Delta (Chai, Chao and Ateljevich, personal communication) to aid in management of freshwater flows, nutrients and fishery problems. Ongoing field and laboratory studies will provide ample data for validation of such additions to the model. The basic model (without flow) can be used to interpret nutrient/phytoplankton interactions in experimental mesocosms. The biogeochemical model (in the mode with flow) is easy to initiate and can be applied to other urban estuaries with anthropogenic nutrient loading and freshwater flow concerns and be used to test possible management scenarios.

\section{Acknowledgments}

This material is based upon work supported by the Delta Stewardship Council under Grant No. 1039. Enclosure experiments conducted in the Sacramento River were funded by the Federal and California State Water Contractors, the San Luis and DeltaMendota Water Authority and California Regional Water Quality Control Board Region 5. We wish to thank Drs Fei Chai and Steve Culberson for critical reading of the manuscript.

\section{References}

Alpine, A.E., Cloern, J.E., 1992. Trophic interactions and direct physical effects control phytoplankton biomass and production in an estuary. Limnol. Oceanogr. 37 946-955.

Ball, M.D., 1977. Phytoplankton Growth and Chlorophyll Levels in the SacramentoSan Joaquin Delta Through San Pablo Bay. U.S. Bureau of Reclamation Sacramento, CA, pp. 96 
Ball, M.D., Arthur, J.F., 1979. Planktonic chlorophyll dynamics in the northern San Francisco Bay and Delta. In: Conomos, J. (Ed.), San Francisco Bay: The Urbanized Estuary Investigations into the Natural History of San Francisco Bay and Delta With Reference to the Influence of Man. Pacific Division, AAAS, San Francisco, pp. 265-286.

Berg, G.M., Glibert, P.M., Jorgensen, N.O.G.M., Balode, M., Purina, I., 2001. Variability in inorganic and organic nitrogen uptake associated with riverine nutrient input in the Gulf of Riga, Baltic Sea. Estuaries 24, 176-186.

Blaser, S., MSc Thesis 2012. Effect of herbicide (diuron and imazapyr) on phytoplankton of San Francisco Bay. San Francisco State University, pp. 96.

Blaser, S., Parker, A.E., Wilkerson, F.P., 2011. Diuron and imazapyr herbicides impact estuarine phytoplankton carbon assimilation: evidence from an experimental study. IEP Newsletter 24 (3), 3-11.

Boynton, W.R., Kemp, W., Keefe, C.W., 1982. Comparative analysis of nutrients and other factors influencing estuarine phytoplankton production. In: Estuarine Comparisons. Proceedings of the Sixth Biennial International Estuarine Research Conference, Gleneden Beach, Oregon, pp. 69-90.

Chai, F., Dugdale, R.C., Peng, T.-H., Wilkerson, F.P., Barber, R.T., 2002. One dimensional ecosystem model of the Equatorial Pacific upwelling system. Part I: Model development and silicon and nitrogen cycle. Deep Sea Res. II 49, 2713-2745.

Cloern, J.E., Dufford, R., 2005. Phytoplankton community ecology: principles applied in San Francisco Bay. Marine Ecology Progress Series 285, 1-28.

Cole, B.E., Cloern, J.E., 1984. Significance of biomass and light availability to phytoplankton productivity in San Francisco Bay. Marine Ecology Progress Series 17, $15-24$.

Di-Torro, D.M., Thomann, R.V., O'Connor, D.J., Mancini, J.L., 1977. Estuarine phytoplankton biomass models-verification analyses and preliminary applications. In: Goldberg, E.D., McCave, I.N., O’Brien, J.J., Steele, J.H. (Eds.), The Sea, Ideas and Observations on Progress in the Study of the Seas, 6. John Wiley, N.Y, pp. 969-1020.

Dugdale, R.C., Wilkerson, F.P., 1986. The use of $15 \mathrm{~N}$ to measure nitrogen uptake in eutrophic oceans; experimental considerations. Limnol. Oceanogr. 31, 673-689.

Dugdale, R.C.F.P., Wilkerson, F.P., Morel, A., 1990. Modeling new production in upwelling centers: I Applications of a shift-up model to 3 upwelling areas. Limnol. Oceanogr. 35, 822-829.

Dugdale, R.C., Barber, R.T., Chai, F., Peng, T.H., Wilkerson, F.P., 2002. One dimensional ecosystem model of the equatorial Pacific upwelling system. Part II: Sensitivity analysis and comparison with JGOFS EqPac Data. Deep-Sea Res. II 49, 2747-2768.

Dugdale, R.C., Wilkerson, F.P., Hogue, V.E., Marchi, A., 2006. Nutrient controls on new production in the Bodega Bay, California, coastal upwelling plume. Deep-Sea Res. Part II 53, 3049-3062.

Dugdale, R.C., Wilkerson, F.P., Hogue, V.E., Marchi, A., 2007. The role of ammonium and nitrate in spring bloom development in San Francisco Bay. Est. Coast. Shelf Sci. 73, 17-29.

Dugdale, R.C., Wilkerson, F.P., Parker, A.E., Marchi, A., Taberski, K., 2012. River flow and ammonium discharge determine spring phytoplankton blooms in an urbanized estuary. Est. Coast. Shelf Sci. 115, 187-199.

Glibert, P.M., Harrison, P.J., Heil, C.A., Seitzinger, S., 2006. Escalating worldwide use of urea-a global change contributing to coastal eutrophication. Biogeochem 77, 441-463.

Glibert, P.M., Fullerton, D., Burkholder, J.M., Cornwell, J., Kana, T.M., 2011. Ecological stoichiometry, biogeochemical cycling, invasive species, and aquatic food webs: San Francisco Estuary and comparative systems. Rev. Fish. Sci. 19, 358-417.

Greene, V.E., Sullivan, L.J., Thompson, J.K., Kimmerer, W.J., 2011. Grazing impact of the invasive clam Corbula amurensis on the microplankton assemblage of the northern San Francisco Estuary. Mar. Ecol. Prog. S 431, 183-193.

Jassby, A.D., 2008. Phytoplankton in the upper San Francisco Estuary: recent biomass trends, their causes and their trophic significance. San Francisco Estuary Watershed Sci. 6, 1-24 http://www.escholarship.org/uc/item/71h077r1
Jassby, A.D., Cloern, J.E., Cole, B.E., 2002. Annual primary production: Patterns and mechanisms of change in a nutrient-rich tidal ecosystem. Limnol. Oceanogr. 47, 698-712.

Kimmerer, W.J., Ferm, N., Nicolini, M.H., Peñalva, C., 2005. Chronic food limitation of egg production in populations of copepods of the genus Acartia in the San Francisco Estuary. Estuaries 28, 541-550.

Kimmerer, W.J.A.E., Parker, A.E., Lidstrom, U., Carpenter, E.J., 2012. Shortterm and interannual variability in primary productivity in the low-salinity zone of the San Francisco Estuary. Estuaries Coasts, http://dx.doi.org/10. 1007/s12237-012-9482-2.

Müller-Solger, A., Jassby, A.D., Muller-Navarra, D., 2002. Nutritional quality of food resources for zooplankton (Daphnia) in a tidal freshwater system (SacramentoSan Joaquin River Delta). Limnol. Oceanogr. 47, 1468-1476.

Nixon, S.W., 1988. Physical energy inputs and the comparative ecology of lake and marine ecosystems. Limnol. Oceanogr. 33, 1005-1025.

Nixon, S.W., 1990. Eutrophication and the macroscope. In: By, J., Andersen, D.J., Conley (Eds.), Eutrophication in Coastal Ecosystems: Towards Better Understanding. Springer, pp. 5-21.

NOAA (National Oceanic and Atmospheric Administration), 2009. Assessment of Environmental Contaminants Associated with the National Defense Reserve Fleet in Suisun bay, CA, Office of Response and Restoration February 2009. 46 pp.

Parker, A.E., Hogue, V.E., Wilkerson, F.P., Dugdale, R.C., 2012a. The effect of inorganic nitrogen speciation on primary production in San Francisco Estuary. Est. Coast. Shelf Sci 104-105, 91-101.

Parker, A.E., Wilkerson, F.P., Dugdale, R.C., 2012b. Elevated ammonium concentrations from wastewater discharge depress primary productivity in the Sacramento River and the northern San Francisco Estuary. Mar. Poll. Bull. 64, 574-586.

Peterson, D.H., Smith, R.E., Hager, S.W., Harmon, D.D., Herndon, R.E., Schemel, L.E., 1985. Interannual variability in dissolved inorganic nutrients in Northern San Francisco Bay Estuary. Hydrobiology 129, 37-58.

Schemel, L.E., Hager, S.W., 1986. Chemical variability in the Sacramento River and in Northern San Francisco Bay. Estuaries 9, 270-283.

Sobczak, W.V., Cloern, J.E., Jassby, A.D., Cole, B.E., Schraga, T.S., Arnsberg, A., 2005. Detritus fuels ecosystem metabolism but not metazoan food webs in San Francisco estuary's freshwater Delta. Estuaries 28, 124-137.

Sommer, T.R., Armor, C., Baxter, R., Breuer, R., Brown, L., Chotkowski, M., Culberson, S., Feyrer, F., Gingas, M., Herbold, B., Kimmerer, W., Müller-Solger, A., Nobriga, M., Souza, K., 2007. The collapse of the pelagic fishes in the upper San Francisco Estuary. Fisheries 32, 270-276.

Syrett, P.J., 1981. Nitrogen metabolism of microalgae. In: Platt, T. (Ed.), Physiological bases of phytoplankton ecology. Can. Bull. Fish Aq. Sci., 210, pp. 182-210.

US EPA, 1988. US EPA. Short-term methods for estimating the chronic toxicity of effluents and receiving waters to marine and estuarine organisms. US EPA Technical Report EPA/600/4-87-028, Cincinnatti, OH.

Wilkerson, F.P., Dugdale, R.C., 1987. The use of large shipboard barrels and drifters to study the effects of coastal upwelling on phytoplankton nutrient dynamics. Limnol. Oceanogr. 32, 368-382.

Wilkerson, F.P., Dugdale, R.C., Chavez, F.P., Kudela, R.M., 2000. Biomass and productivity in Monterey Bay, California: contribution of the larger autotrophs. Deep-Sea Res. II 47, 1003-1022.

Wilkerson, F.P., Dugdale, R.C., Hogue, V.E., Marchi, A., 2006. Phytoplankton blooms and nitrogen productivity in San Francisco Bay. Estuaries Coasts 29, 401-4176.

Xiu, P., Chai, F., 2012. Spatial and temporal variability in phytoplankton carbon, chlorophyll, and nitrogen in the North Pacific. Journal of Geophysical Research 117, C11023, http://dx.doi.org/10.1029/2012JC008067. 